UNIVERSIDADE ESTADUAL PAULISTA “JÚLIO DE MESQUITA FILHO” FACULDADE DE CIÊNCIAS AGRONÔMICAS CAMPUS DE BOTUCATU

\title{
CARACTERIZAÇÃO FÍSICO-QUÍMICA, ENERGÉTICA E SENSORIAL DE REFRESCO ADOÇADO DE JABUTICABA
}

FRANCINE FRICHER BOESSO

Dissertação apresentada à Faculdade de Ciências Agronômicas da UNESP - Campus de Botucatu, para obtenção do título de Mestre em Agronomia (Energia na Agricultura).

BOTUCATU - SP

Fevereiro - 2014 
UNIVERSIDADE ESTADUAL PAULISTA “JÚLIO DE MESQUITA FILHO” FACULDADE DE CIÊNCIAS AGRONÔMICAS

CAMPUS DE BOTUCATU

\section{CARACTERIZAÇÃO FÍSICO-QUÍMICA, ENERGÉTICA E SENSORIAL DE REFRESCO ADOÇADO DE JABUTICABA}

\section{FRANCINE FRICHER BOESSO}

Orientador: Prof. Dr. Waldemar Gastoni Venturini Filho

Dissertação apresentada à Faculdade de Ciências Agronômicas da UNESP - Campus de Botucatu, para obtenção do título de Mestre em Agronomia (Energia na Agricultura).

BOTUCATU - SP

Fevereiro - 2014 
FICHA CATALOGRÁFICA ELABORADA PELA SEÇÃO TÉCNICA DE AQUISIÇÃo E TRATAMENTO DA INFORMAÇÃO - SERVIÇO TÉCNICO DE BIBLIOTECA E DOCUMENTAÇĀO - UNESP - FCA - LAGEADO - BOtUCATU (SP)

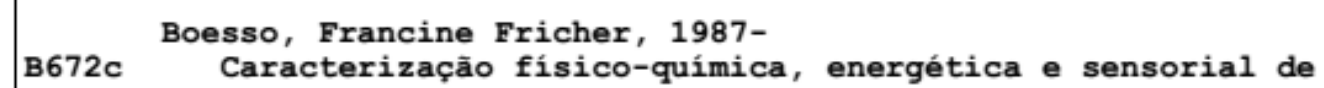

1. Jabuticaba - Processamento. 2. Bebidas não-alcoólicas. 3. Suco de frutas. I. Venturini Filho, Waldemar Gastoni. II. Universidade Estadual Paulista "Júlio de Mesquita Filho" (Campus de Botucatu). Faculdade de Ciências Agronômicas. III. Título. 


\section{UNIVERSIDADE ESTADUAL PAULISTA "JÚLIO DE MESQUITA FILHO"}

\section{FACULDADE DE CIÊNCIAS AGRONÔMICAS}

CAMPUS DE BOTUCATU

CERTIFICADO DE APROVAÇÃO

TÍTULO: "CARACTERIZAÇÃO FÍSICO-QUIMICA, ENERGÉTICA E SENSORIAL DE REFRESCO ADOÇADO DE JABUTICABA"

ALUNA: FRANCINE FRICHER BOESSO

ORIENTADOR: PROF. DR. WALDEMAR GASTONI VENTURINI FILHO

Aprovado pela Comissão Examinadora

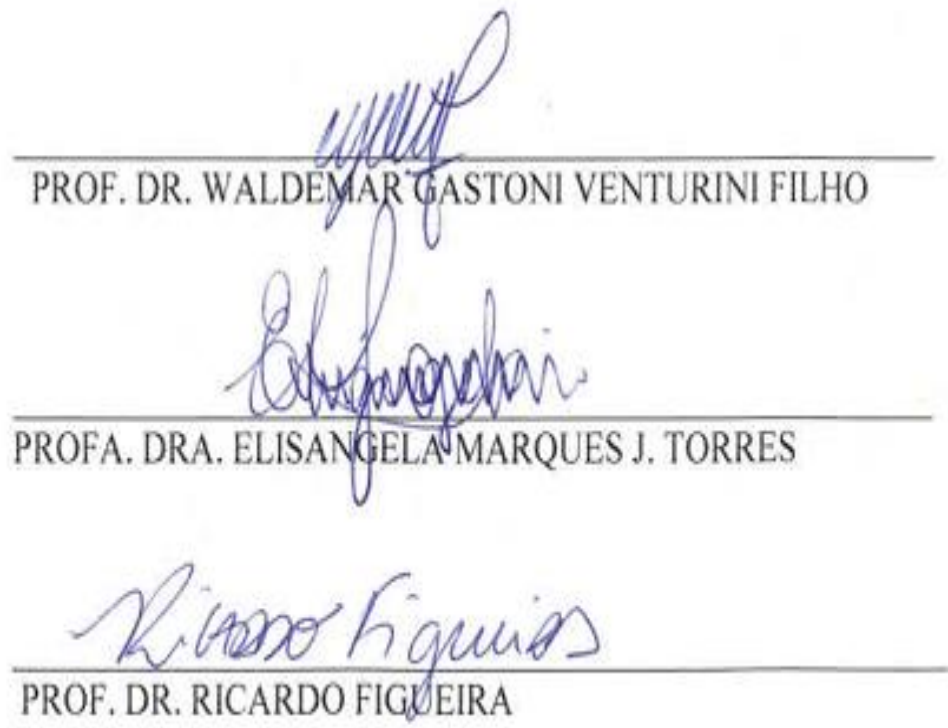

Data da Realização: 28 de fevereiro de 2014. 


\section{AGRADECIMENTOS}

Primeiramente agradeço aos meus pais que sempre prezaram pela educação e mesmo não estando mais presentes me deram suporte para que mais essa etapa fosse completada, sem eles nada seria possível!

À Faculdade de Ciências Agronômicas - FCA/UNESP - Campus de Botucatu, seus professores, funcionários e alunos.

Ao Programa de Pós-Graduação em Energia na Agricultura, pela oportunidade concedida.

Ao Prof. Dr. Waldemar Gastoni Venturini Filho pela oportunidade, orientação e amizade.

Aos amigos e colegas do Laboratório de Bebidas que muito me ajudaram durante todo este trabalho.

Ao meu irmão, Fernando Fricher Boesso, que sempre esteve ao meu lado, torcendo por mais essa conquista.

Ao meu namorado, Julio Cesar Martins, que me acompanhou nos momentos mais alegres e nos mais difíceis desses anos. A você, eu agradeço pela força e incentivo para confiar e continuar nesse caminho, pela paciência e compreensão nas horas difíceis, por todo amor e carinho que me fortalecem.

Todas às outras pessoas que, de alguma maneira, contribuíram para a realização deste trabalho. 


\section{SUMÁRIO}

Página

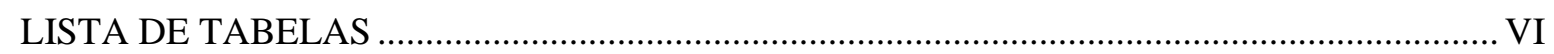

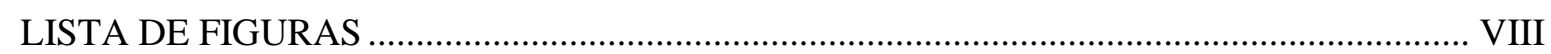

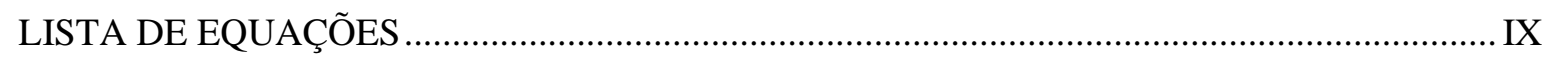

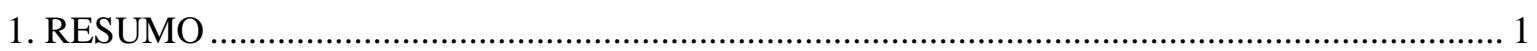

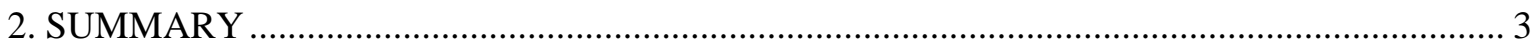

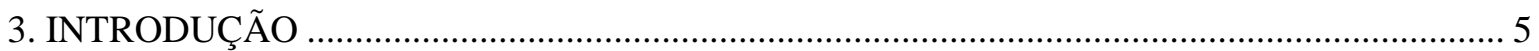

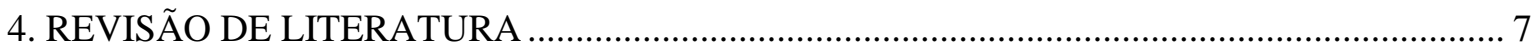

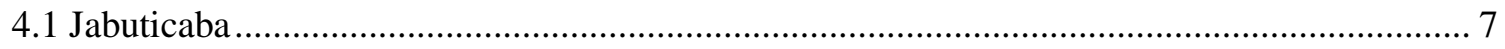

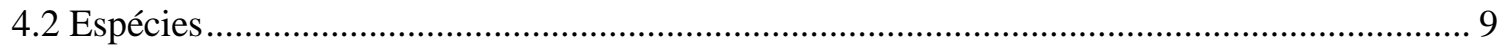

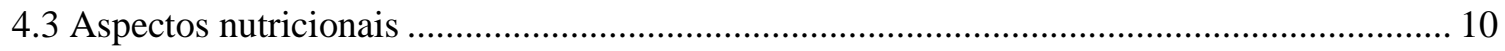

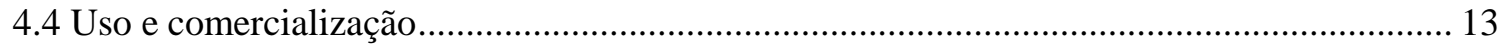

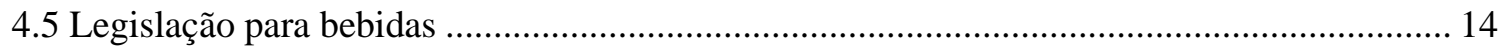

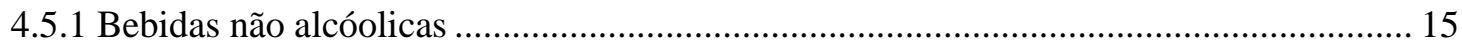

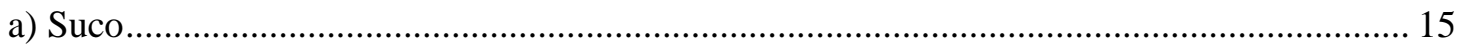

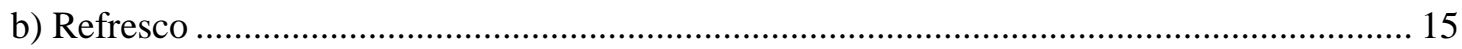

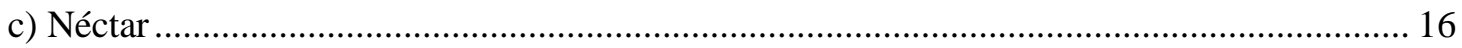

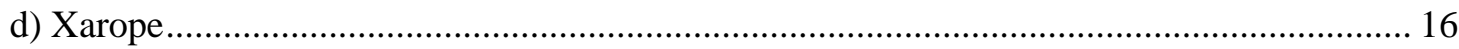

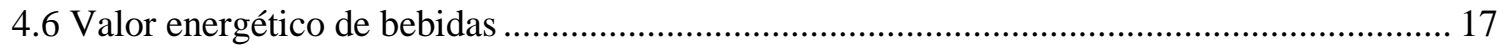

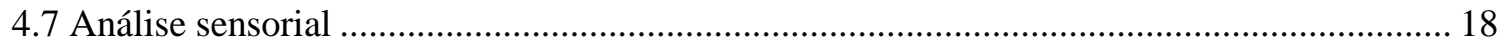

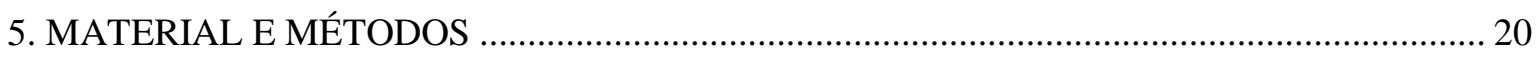

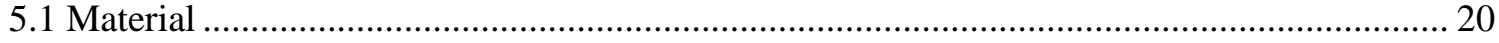

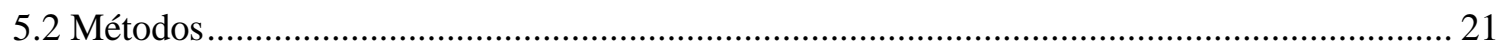

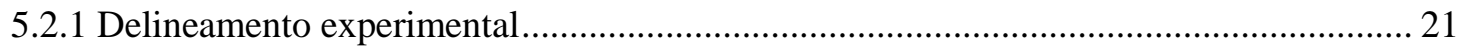

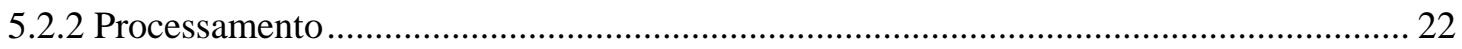

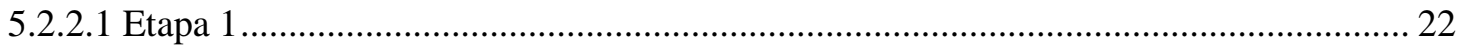

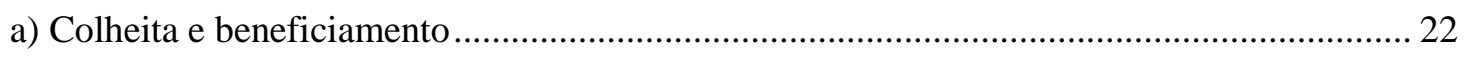

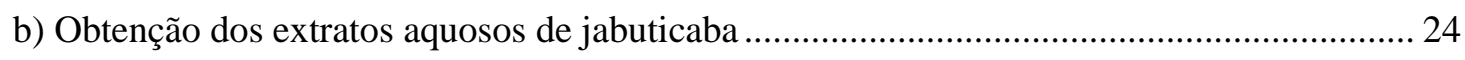

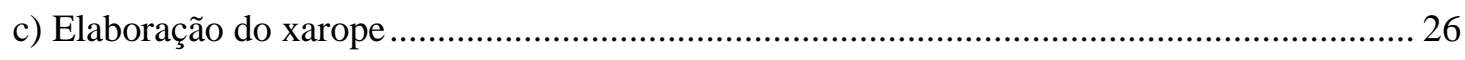

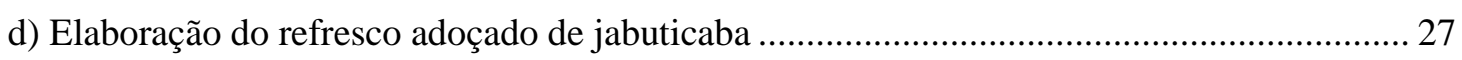

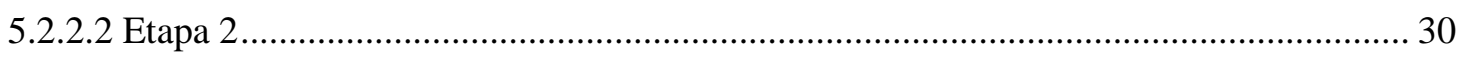

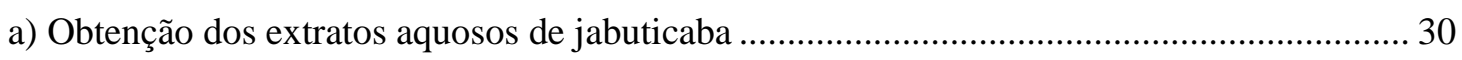

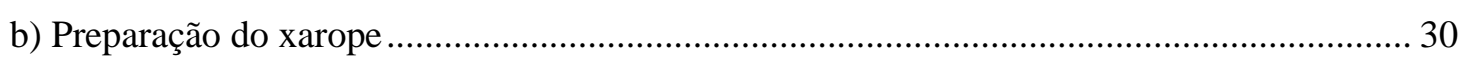

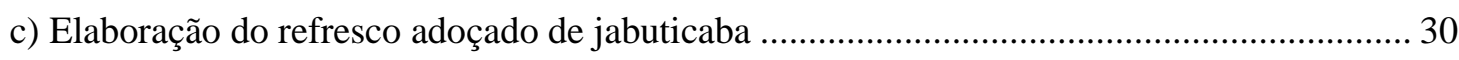




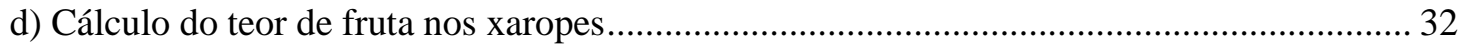

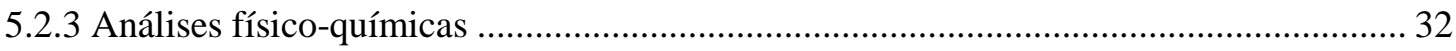

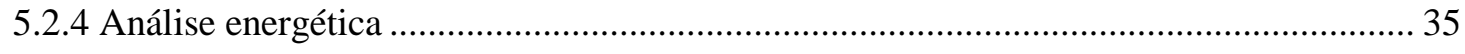

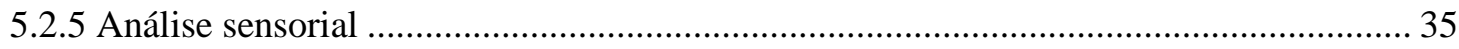

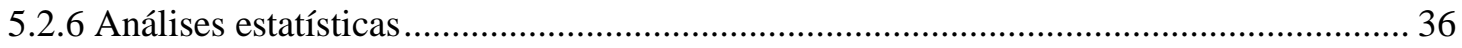

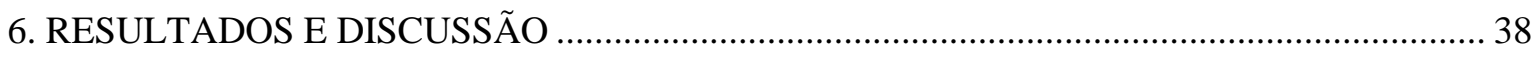

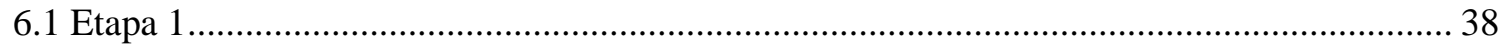

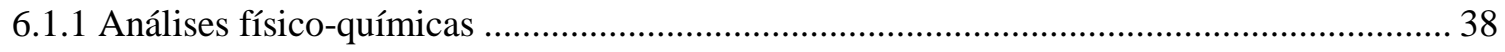

6.1.2 Composição centesimal e valor energético .......................................................................... 43

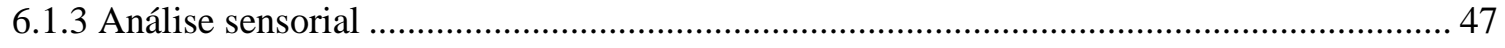

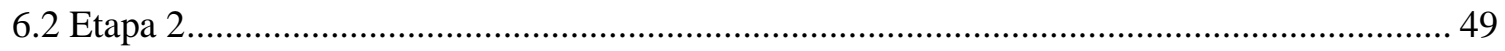

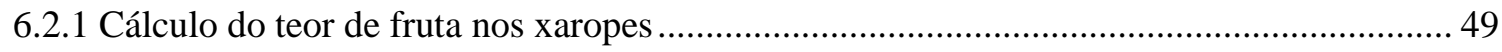

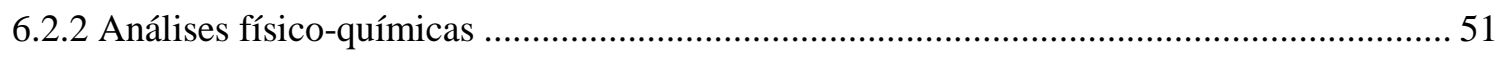

6.2.3 Composição centesimal e valor energético …………………............................................ 53

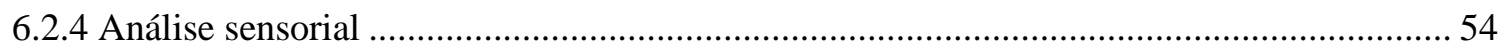

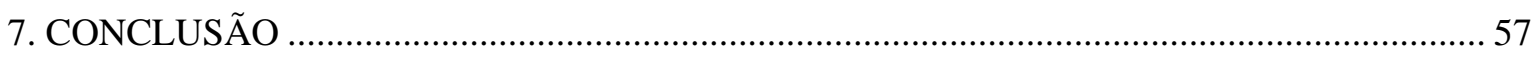

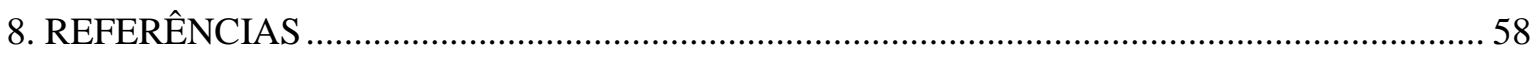

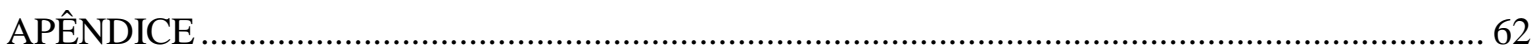




\section{LISTA DE TABELAS}

Tabela 1. Composição química da polpa de jabuticaba Sabará in natura.....

Tabela 2. Composição centesimal de parte comestível da jabuticaba crua conforme a TACO.

Tabela 3. Tratamentos realizados na etapa 1 do projeto .22

Tabela 4. Significâncias estatísticas obtidas pelo teste F para as análises físico-químicas realizadas nos refrescos adoçados de jabuticaba.

Tabela 5. Médias das variáveis físico-químicas, seguidas do desvio padrão, dos refrescos adoçados de jabuticaba

Tabela 6. Significâncias estatísticas obtidas pelo teste F para a composição centesimal e valores energéticos dos refrescos adoçados de jabuticaba

Tabela 7. Valores médios da composição centesimal e do valor energético dos refrescos adoçados de jabuticaba

Tabela 8. Significâncias estatísticas obtidas pelo teste $\mathrm{F}$ para as análises sensoriais realizadas nos refrescos de jabuticaba.

Tabela 9. Comparação de médias das notas, seguidas do desvio padrão, dos atributos sensoriais aparência, aroma, sabor e avaliação global dos refrescos de jabuticaba. .48

Tabela 10. Significâncias estatísticas obtidas pelo teste F para os teores de fruta e açúcar presente nos xaropes elaborados. .50

Tabela 11. Médias das percentagens do teor de fruta e açúcar presente nos xaropes elaborados, seguida pelo desvio padrão. .50

Tabela 12. Significâncias estatísticas obtidas pelo teste F para as análises físico-químicas realizadas nos refrescos adoçados de jabuticaba a $12^{\circ}$ Brix. 
Tabela 13. Médias das variáveis físico-químicas, seguidas do desvio padrão, dos refrescos adoçados de jabuticaba a $12^{\circ}$ Brix

Tabela 14. Significâncias estatísticas obtidas pelo teste F para a composição centesimal e valores energéticos dos refrescos adoçados de jabuticaba a $12^{\circ}$ Brix .53

Tabela 15. Valores médios, seguidos pelo desvio padrão, da composição centesimal e do valor energético dos refrescos adoçados de jabuticaba a $12^{\circ}$ Brix. .54

Tabela 16. Significâncias estatísticas obtidas pelo teste F para as análises sensoriais realizadas nos refrescos adoçados de jabuticaba a $12^{\circ}$ Brix .55

Tabela 17. Comparação de médias, seguidas pelo desvio padrão, dos atributos sensoriais aparência, aroma, sabor e avaliação global dos refrescos de jabuticaba a $12^{\circ}$ Brix .56 


\section{LISTA DE FIGURAS}

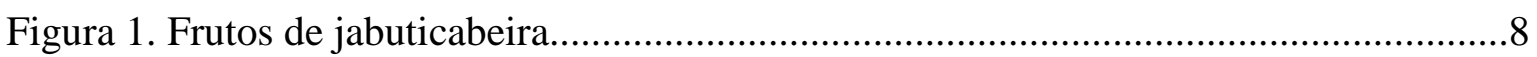

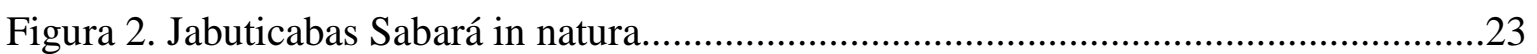

Figura 3. Etapa de drenagem do excesso de água..............................................................23

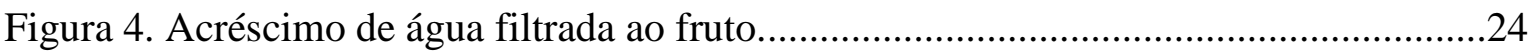

Figura 5. Aquecimento em fogo direto da mistura (jabuticaba esmagada com água

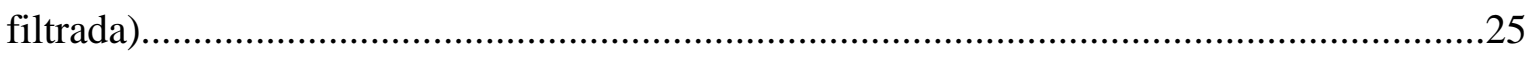

Figura 6. Aquecimento em fogo direto da mistura (jabuticaba inteira com água

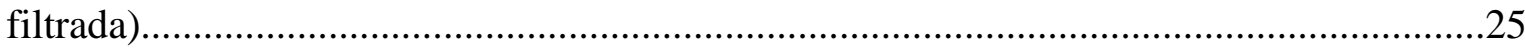

Figura 7. Filtração em voil para separação do extrato e do bagaço......................................26

Figura 8. Acondicionamento do xarope em garrafas de vidro..........................................27

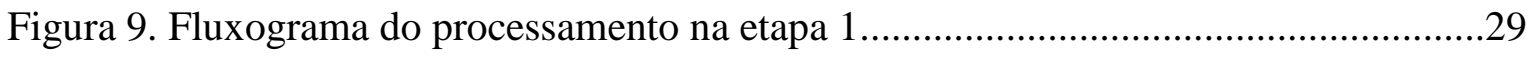

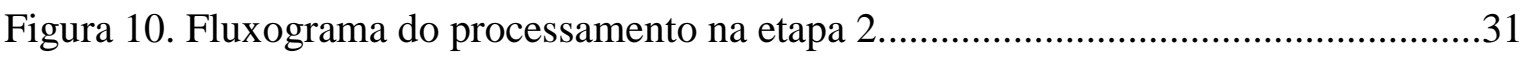

Figura 11. Ficha modelo do teste de escala hedônica......................................................... 


\section{LISTA DE EQUAÇÕES}

Equação 1. Balanço de massa para a produção do xarope..................................................26

Equação 2. Balanço de massa para a produção do refresco.................................................27

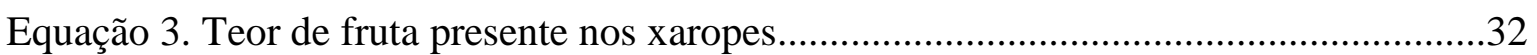

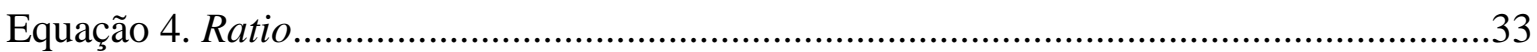

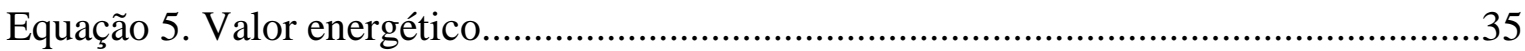




\section{RESUMO}

O objetivo do presente trabalho foi produzir e caracterizar por meio de análises físico-químicas, energéticas e sensoriais refrescos adoçados de jabuticaba, visando o aproveitamento tecnológico e agregação de valor a frutos de jabuticabeira. As matérias-primas utilizadas foram jabuticabas Sabará, açúcar cristal e água duplamente filtrada. O experimento foi desenvolvido em duas etapas. Os ensaios de produção de refresco adoçado de jabuticaba na etapa 1 foram desenvolvidos a partir de seis tratamentos, combinando-se dois métodos de extração de sólidos solúveis (utilizando a jabuticaba inteira e esmagada) e três formulações do refresco adoçado de jabuticaba com diferentes concentrações de sólidos solúveis (10, 12 e 14 ${ }^{\circ}$ Brix). Na etapa 2 os refrescos adoçados de jabuticaba foram elaborados a partir da diluição do xarope $\left(60\right.$ e $70^{\circ}$ Brix $)$ para obtenção dos refrescos à $12^{\circ}$ Brix. Em todos os experimentos os refrescos adoçados de jabuticaba foram analisados físico-quimicamente em relação aos teores de sólidos solúveis, $\mathrm{pH}$, acidez total, ratio, açúcares redutores, açúcares redutores totais, turbidez, bem como tiveram os teores de nutrientes (carboidratos, proteínas, lipídeos, umidade e cinzas) e 
valores energéticos determinados por meio de análise centesimal. A análise sensorial foi realizada por meio de testes afetivos de aceitação. Na etapa 1, o método de extração, a concentração de sólidos solúveis e a interação desses fatores interferiram nas variáveis físicas (turbidez) e químicas ( ${ }^{\circ} \mathrm{Brix}$, acidez total, $\mathrm{AR}$ e cálculo do ratio) de todas as amostras das bebidas elaboradas neste experimento, com exceção dos valores de $\mathrm{pH}$ e ART. Energeticamente o método de extração influenciou os teores de proteínas e lipídios presentes nos refresco adoçados de jabuticaba. Os refrescos não apresentaram diferença sensorial quanto ao método de extração utilizado (jabuticaba inteira $\mathrm{x}$ jabuticaba esmagada), mas apresentaram diferença sensorial significativa quanto à concentração de sólidos solúveis presente no refresco (10, 12 e $14^{\circ}$ Brix) sendo os refrescos de 12 e $14^{\circ}$ Brix os mais apreciados sensorialmente em todos os atributos (aparência, aroma, sabor e avaliação geral). Na etapa 2 da pesquisa, verificou-se que os xaropes com concentração de sólidos solúveis a $60^{\circ}$ Brix apresentaram maior teor de fruta em sua composição. Os resultados das análises físico-químicas apontaram que a variação no teor de sólido solúveis dos xaropes interferiu significativamente em praticamente todos os parâmetros dos refrescos adoçados de jabuticaba, exceto nos parâmetros turbidez e açúcar redutor total, bem como, na aparência das bebidas, resultando em médias mais elevadas para os refrescos adoçados de jabuticaba provenientes da diluição do xarope $60^{\circ}$ Brix. As análises energéticas apontaram que a única variável que apresentou diferença significativa em relação à variação no teor de sólidos solúveis dos xaropes foi a umidade sendo esta maior no xarope com maior teor de fruta em sua composição.

Palavras-chave: Myrciaria jaboticaba (Vell) Berg; bebida; processamento. 
PHYSICO-CHEMICAL CHARACTERIZATION, ENERGY AND SENSORY SOFT SWEETENED JABOTICABA. Botucatu, 2014. 64p. Dissertação (Mestrado em Agronomia / Energia na Agricultura) Faculdade de Ciências Agronômicas, Universidade Estadual Paulista.

Author: FRANCINE FRICHER BOESSO

Adviser: WALDEMAR GASTONI VENTURINI FILHO

\section{SUMMARY}

The aim of this work was to produce and characterize through physical- chemical, energy and soft drinks sweetened jaboticaba sensory analyzes, aiming to use technology and adding value to the fruits. The raw materials used were jaboticaba Sabara, crystal sugar and doubly filtered water. The experiment was conducted in two stages. Assays of producing sweetened soft drink jaboticaba in step 1 were developed from six treatments combining two methods of extraction of soluble solids ( using the whole and crushed blemish blemish) and three formulations of soft drink sweetened with different concentrations jaboticaba soluble solids $\left(10,12\right.$ and $14^{\circ}$ Brix $)$. In step 2 the soft drink sweetened jaboticaba were prepared by diluting the syrup (60 and $70^{\circ}$ Brix) for obtaining refreshments at $12^{\circ}$ Brix. In all experiments jaboticaba sweetened soft drinks were analyzed physico-chemically with respect to soluble solids, $\mathrm{pH}$, total acidity, ratio, reducing sugars, total reducing sugars, turbidity, and had the levels of nutrients (carbohydrates, proteins, 
lipid, moisture and ash) and energy values determined by proximate analysis. Sensory analysis was performed by means of affective acceptance tests. In step 1, the extraction method, the concentration of soluble solids and the interaction of these factors interfered with physical (turbidity) and chemical variables ( ${ }^{\circ}$ Brix, total acidity, and calculation of the AR ratio) of all samples of beverages prepared in this experiment, except for the values $\mathrm{pH}$ and ART. The energy extraction method influenced the levels of proteins and lipids present in soft drink sweetened jaboticaba. Refreshments showed no sensory difference to the extraction method used, but showed significant sensory difference in the concentration of soluble solids present in soft drink (10, 12 and $\left.14^{\circ}\right)$ and refreshments 12 and $14^{\circ}$ Brix and the most appreciated in all sensory attributes (appearance, aroma, flavor and overall). In step 2 of the study, it was found that the syrup with concentration of soluble solids at $60^{\circ}$ Brix fruit showed a high level in the composition. The results of physico-chemical analysis showed that the variation in soluble solid content of syrups interfered significantly in virtually all parameters of soft drinks sweetened jaboticaba except the parameters turbidity and total reducing sugar, as well as the appearance of beverages, resulting in higher averages for refreshments sweetened jaboticaba from dilution of $60^{\circ}$ Brix syrup. Energy analyzes showed that the only variable that showed significant difference in the change in soluble solid content of syrups was the humidity being higher in this syrup with higher fruit content in their composition .

Keywords: Myrciaria jaboticaba (Vell) Berg; drink; processing. 


\section{INTRODUÇÃO}

A jabuticabeira (Myrciaria cauliflora Berg) é uma árvore frutífera pertencente à família Myrtaceae, de ocorrência espontânea em grande parte do Brasil. A espécie mais difundida é a $M$. jaboticaba (Vell) Berg, sendo a 'Sabará' a mais apreciada e intensamente plantada.

A jabuticaba é uma fruta que tem despertado grande interesse entre os produtores rurais devido a sua alta produtividade, rusticidade e aproveitamento de seus frutos nas mais diferentes formas, apresentando assim grande potencial econômico. $\mathrm{O}$ fruto in natura e os produtos obtidos a partir de seu processamento (vinho, geleia, vinagre, aguardente, licor) são bastante apreciados pelos consumidores (BRUNINI et al., 2004).

O setor de bebidas, principalmente as não alcoólicas, a exemplo dos sucos de fruta, tem apresentado constante crescimento em função tanto do aumento do volume de produção, quanto do aumento do consumo per capita. Os consumidores apresentam uma maior tendência ao uso de alimentos considerados saudáveis, e por isso aumentaram o consumo de bebidas à base de frutas e de extratos vegetais, soja, chás, águas e isotônicos. As indústrias de alimentos já estão atentas para esse fato, e buscam novos 
tipos de bebidas, sabores, nichos de mercado, além de melhorar a sua qualidade e popularizar seu uso (DE MARCHI, 2006).

A jabuticaba é um fruto de elevado valor nutricional. Segundo a Tabela Brasileira de Composição dos Alimentos - TACO (BRASIL, 2011), esta fruta é uma fonte considerável de água, carboidratos, fibras alimentares, sais minerais e vitamina C. O elevado valor nutricional desses frutos também está relacionado à presença significativa de compostos fenólicos em sua composição, principalmente na casca. Dentre os compostos fenólicos presentes no fruto, os flavonóides são um dos grupos mais importantes e se destacam por suas propriedades antioxidantes.

Devido ao elevado teor de água e açúcares presentes na polpa a jabuticaba é uma fruta altamente perecível. Embora apresente características organolépticas interessantes, os frutos não tem tido aproveitamento comercial, devido à elevada perecibilidade e curto período de safra. Diante disso, objetivou-se estudar o processamento de frutos de jabuticabeira visando o aproveitamento tecnológico $\mathrm{e}$ agregação de valor à fruta por meio da produção e caracterização físico-química, energética e sensorial de refresco adoçado de jabuticaba. 


\section{REVISÃO DE LITERATURA}

\subsection{Jabuticaba}

A jabuticabeira (Myrciaria sp.), pertencente à família Myrtaceae, é uma árvore frutífera caracteristicamente brasileira (OCHSE et al, 1961), espontânea na maior parte do Brasil, sendo mais comum nas regiões Centro-Sul, Sudeste e Sul do país (GOMES, 1972).

De origem subtropical e nativa do Bioma Mata Atlântica (CITADIN; DANNER; SASSO, 2010) as jabuticabeiras se adaptam em diferentes climas e apresentam uma extraordinária capacidade de vegetar em diversos tipos de solos, porém preferem os sílico-argilosos e os argilo-silocosos profundos, ricos em matéria orgânica e bem drenados (GOMES, 1972). O crescimento é vagaroso, podendo levar de oito a quinze anos para o início de sua produção (MATTOS, 1983). Propagada principalmente por via seminífera a jabuticabeira também pode ser propagada assexuadamente por estaquia ou 
mergulhia, métodos pouco usados, pois essa espécie é considerada de difícil enraizamento (MANICA, 2000).

Árvore de porte médio, com 6 a $9 \mathrm{~m}$ de altura, podendo alcançar de 10 a $15 \mathrm{~m}$ de altura, a jabuticabeira apresenta porte piramidal e copa com forma variada e muito densa, ramos e troncos lisos de cor amarelo avermelhados que apresentam como característica típica a ruptura, em placas, da casca (ANDERSEN; ANDERSEN, 1989). As folhas são opostas, lanceoladas, vermelhas quando jovem e verde posteriormente com comprimento variando entre 2,4 a 4,3 cm por 0,6 a 1,6 cm de largura. Florescem mais de uma vez ao ano com flores brancas e sésseis que surgem diretamente no caule. Frutifica fartamente cobrindo de frutos o tronco, os galhos e até as raízes descobertas (DONADIO; MÔRO; SERVIDONE, 2002).

Três meses após a floração a jabuticabeira inicia a frutificação; com adubação mais intensa e sob regime de irrigação, a planta pode dar duas a três floradas ao ano. O ponto de maturação dos frutos é mostrado pela cor (conforme a espécie) e quando o mesmo estiver macio à compressão com os dedos. A colheita é efetuada manualmente, com auxilio de escadas. Os frutos são colocados em sacos a tiracolo, sem contato direto com o solo, desses sacos passam a cestas ou caixas pequenas, para evitar esmagamento e sem forro, para circular ar. Contendo casca consistente o fruto apresenta boa conservação e resiste bem ao transporte (GOMES, 1972).

A jabuticaba, fruto da jabuticabeira, apresenta-se sob a forma de uma baga globulosa, com até três $\mathrm{cm}$ de diâmetro, casca avermelhada quase preta, polpa esbranquiçada, mucilaginosa, agridoce, envolvendo de uma a quatro sementes como apresenta a Figura 1 (LIMA et al., 2008).

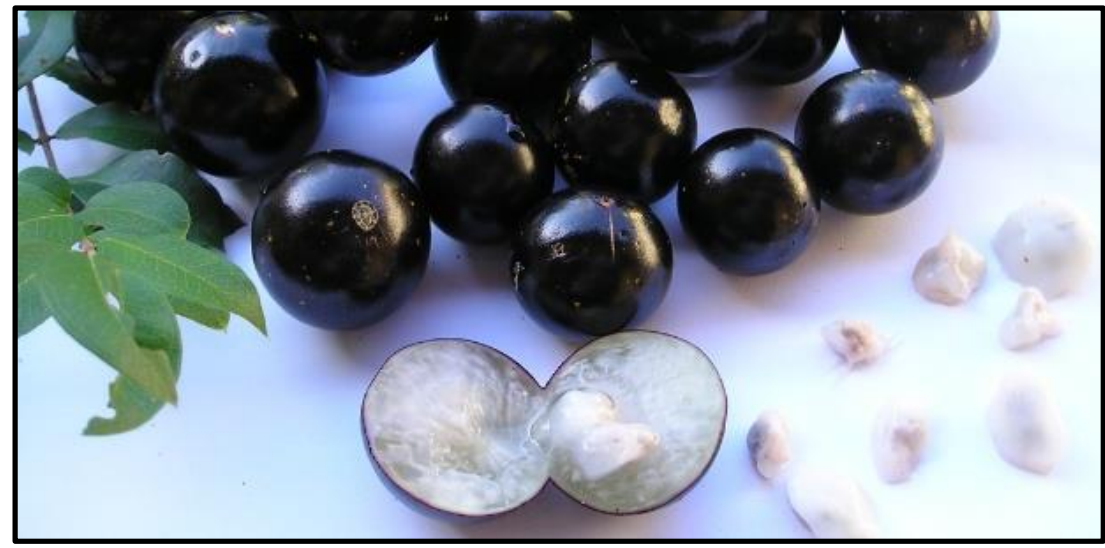

Figura 1. Frutos de jabuticabeira. Fonte: Temporada (2012). 


\subsection{Espécies}

São conhecidas nove espécies, sendo que uma está extinta, cinco são encontradas apenas em alguns sítios de pesquisa e somente três apresentam disseminação natural e em cultivos no Brasil, são elas: Myrciaria spirito-santensis Mattos, Myrciaria aureana Mattos (conhecida como jabuticaba branca), Myrciaria grandifolia Mattos (conhecida como jabuticaba graúda), Myrciaria phitrantha (Kiaersk) Mattos, Myrciaria coronata Mattos (comumente conhecida como jabuticaba coroada, ou jabuticaba de coroa), Myrciaria oblongata Mattos (conhecida como jabuticaba azeda), Myrciaria trunciflora (Berg) Mattos (jabuticaba de cabinho); Myrciaria cauliflora (DC) Berg (jabuticaba paulista, ponhema ou assu); e Myrciaria jaboticaba (Vell) Berg (jabuticaba Sabará) (CITADIN; DANNER; SASSO, 2010; GOMES, 1972; MATTOS, 1983).

A jabuticaba Paulista possui maior porte do que a Sabará com grande produção e maturação um pouco tardia. Seus frutos são grandes e coriáceos (GOMES, 1972).

Myrciaria trunciflora (Berg) Mattos: árvores com cerca de 8m de altura; ramos cilíndricos, folhas escuras com pecíolos de aproximadamente $3 \mathrm{~mm}$ de comprimento; bagas globosas, com cerca de $2 \mathrm{~cm}$ de diâmetro, negras; 1 a 4 sementes. Também conhecida como jabuticaba de cabinho, ocorre principalmente nos estados de MG e ES, no Brasil, e também no Paraguai e Argentina (BORGES; MELO, 2013).

Myrciaria cauliflora (DC) Berg: possui ramos terminais e achatados; folhas com pecíolos de 3mm de comprimento; frutos globosos, de cor negra, 2,2 a 2,8 cm de comprimento por 2,2 a 2,9 cm de diâmetro; 1 a 4 sementes. Conhecida como Paulista, Assu (ou açu), e Ponhema. Ocorre de forma geral em Brasil (BORGES; MELO, 2013).

Myrciaria jaboticaba (Vell) Berg: é uma árvore de 6 a 9m de altura; ramos finos e cilíndricos, sendo os ramos terminais e novos, achatados; folhas com pecíolo de 1,5 a $2 \mathrm{~mm}$ de comprimento, ciliadas quando novas; frutos de 1,6 a 2,2 $\mathrm{cm}$ de diâmetro, subglobosos ou globosos, negros e lisos; 1 a 4 sementes. Conhecida como Sabará, ocorre no Brasil, Paraguai e Argentina (BORGES; MELO, 2013). É a espécie mais conhecida no Brasil sendo a mais apreciada e doce das jabuticabas. Intensamente cultivada possui alguns pomares comerciais. Apresenta um crescimento médio, mas muito produtiva 
com maturação precoce. Os frutos são miúdos, de epicarpo fino quase preto (GOMES, 1972).

\subsection{Aspectos nutricionais}

Sendo um fruto tropical de grande valor nutricional, a jabuticaba é uma fonte considerável de água, carboidratos, fibras alimentares, vitaminas e sais minerais como ferro, cálcio e fósforo, conforme apresentado nas Tabelas 1 e 2 (ASCHERI et al., 2006).

O elevado valor nutricional desses frutos também está relacionado à presença significativa de compostos fenólicos em sua composição, principalmente na casca (LIMA et al., 2008). Dentre os compostos fenólicos, os flavonóides são um dos grupos mais importantes presente no fruto e se destacam por suas propriedades antioxidantes (SIMÕES et al., 2000).

Tabela 1. Composição química da polpa de jabuticaba Sabará in natura .

\begin{tabular}{|c|c|}
\hline Análises & Polpa in natura \\
\hline Proteínas (\%) & 0,49 \\
\hline Sólidos solúveis totais ( $\left.{ }^{\circ} \mathrm{Brix}\right)$ & 15,90 \\
\hline $\mathrm{pH}$ & 3,75 \\
\hline Acidez titulável (\%) & 0,73 \\
\hline Açúcares redutores (\%) & 12,52 \\
\hline Açúcares não redutores (\%) & 3,08 \\
\hline Açúcares totais $(\%)$ & 17,09 \\
\hline Pectina solúvel (mg.100g $\left.{ }^{-1}\right)$ & 303,86 \\
\hline Pectina total (mg. $\left.100 \mathrm{~g}^{-1}\right)$ & 611,09 \\
\hline Solubilização (\%) & 49,00 \\
\hline Tanino (mg.100g $\mathrm{g}^{-1}$ ) & 259,58 \\
\hline Vitamina C total $\left(\mathrm{mg} \cdot 100 \mathrm{~g}^{-1}\right)$ & 47,22 \\
\hline Amido (\%) & 0,25 \\
\hline Fibra bruta $(\%)$ & 0,09 \\
\hline Fibra em detergente neutro-FDN (\%) & 0,45 \\
\hline
\end{tabular}

Fonte: Campos et al. (2002). 
Tabela 1. Continuação.

\begin{tabular}{|c|c|}
\hline Fibra em detergente ácido-FDA (\%) & 0,27 \\
\hline Lignina $(\%)$ & 0,10 \\
\hline Hemicelulose (\%) & 0,18 \\
\hline Celulose $(\%)$ & 0,18 \\
\hline Peroxidase (mmol.(g.mim) $)^{-1}$ ) & 40,02 \\
\hline Poligalaturanase (mmol.(g.mim) ${ }^{-1}$ ) & 36,77 \\
\hline Polifenoloxidase (mmol.(g.mim) ${ }^{-1}$ ) & 0,00 \\
\hline
\end{tabular}

Fonte: Campos et al. (2002).

Tabela 2. Composição centesimal de parte comestível da jabuticaba crua conforme a TACO.

\begin{tabular}{lc}
\hline \multicolumn{1}{c}{ Análises } & Composição centesimal \\
\hline Umidade (\%) & 83,6 \\
Energia (kcal) & 58,0 \\
Energia (kJ) & 243,0 \\
Proteína (g) & 0,6 \\
Lipídeos (g) & 0,1 \\
Carboidrato (g) & 15,3 \\
Fibra Alimentar (g) & 2,3 \\
Cinzas (g) & 0,4 \\
Cálcio (mg) & 8,0 \\
Ferro (mg) & 0,1 \\
Fósforo (mg) & 15,0 \\
Potássio (mg) & 130,0 \\
Vitamina C (mg) & 16,2 \\
\hline
\end{tabular}

Fonte: BRASIL (2011).

Segundo Lima et al. (2008), para o fruto inteiro obtiveram valores de sólidos solúveis totais (SST) de 12,50 e 11,20³rix para as variedades Paulista e Sabará, respectivamente; os teores de acidez total titulável (ATT) expressos em g de ácido cítrico/100 g de polpa e $\mathrm{pH}$ encontrados foram de, respectivamente, 1,38 e 3,59 para a jabuticaba Paulista e 1,41 e 3,59 para a jabuticaba Sabará. 
OLIVEIRA et al. (2003) caracterizaram jabuticabas da variedade Sabará, provenientes de diferentes regiões de cultivos do estado de São Paulo, e constataram que, em sua polpa, o teor de sólidos solúveis totais (SST) variou de 11,5 a 17,9³rix, os teores de vitamina $\mathrm{C}$ variaram de 14,86 a 24,67 mg de ácido ascórbico por $100 \mathrm{~g}$ de polpa, o pH variou de 2,91 a 3,72, a acidez total titulável (ATT) variou de 0,88 a 1,62 g de ácido cítrico por 100 g de polpa, e os carboidrato solúvel variou de 0,91 a 11,39 $\mathrm{g}$ de glicose por $100 \mathrm{~g}$ de polpa. Estes mesmos autores concluíram que a região de cultivo interfere nas características físico-químicas da jabuticaba 'Sabará'.

Segundo Magalhães et al. (1996), durante o desenvolvimento da jabuticaba verificou-se que o teor de celulose foi predominante entre os carboidratos estruturais, seguido por hemicelulose e finalmente, pectina. Durante o processo de amadurecimento da jabuticaba ocorre ainda, aumento importante na concentração de açúcares nos frutos, sobretudo de açúcares redutores, decréscimo no teor total de amido, diminuição da concentração de clorofila e aumento na quantidade de antocianinas (ZICKER, 2011).

Entre os compostos fenólicos encontrados nos vegetais, estão as antocianinas, que são pigmentos solúveis em água responsáveis por uma grande variedade de cores, que variam do vermelho alaranjado ao vermelho vivo, azul e roxo, de frutos, folhas e flores e apresentam efeitos benéficos à saúde humana como atividade antioxidante (LIMA et al., 2008).

Segundo Lima et al. (2008) os maiores teores de polifenóis em jabuticabas Paulistas e Sabará foram encontrados na casca do fruto, aproximadamente 25 vezes mais que a polpa. Segundo o autor, a espécie Sabará apresentou 0,49 g.100 g ${ }^{-1}$ de polifenóis na polpa e $11,99 \mathrm{~g} .100 \mathrm{~g}^{-1}$ na casca.

Terci (2004) constatou que a jabuticaba apresentou teores de antocianinas entre 310 e $315 \mathrm{mg}$ por $100 \mathrm{~g}$ da fruta, valor considerado alto, semelhante ou maior que outras frutas, como jambolão (de 378 a $386 \mathrm{mg} .100 \mathrm{~g}^{-1}$ ), amora (de 261 a 292 mg. $\left.100 \mathrm{~g}^{-1}\right)$ e uva $\left(227\right.$ a $\left.235 \mathrm{mg} .100 \mathrm{~g}^{-1}\right)$.

Portanto, o valor nutricional é um dos principais fatores que conduzem ao crescente interesse pelo consumo de frutas, embora muitas de menor expressão nacional, em relação ao cultivo e comercialização, ainda não tenham sido devidamente pesquisadas quanto às propriedades e atividades benéficas à saúde do consumidor (JACQUES et al., 2009). 


\subsection{Uso e comercialização}

A jabuticaba é uma fruta muito apreciada tanto para o consumo ao natural como para a fabricação de geleia, xaropes, suco, sorvete, bebidas fermentadas, vinho, vinagre e licores (DONADIO, 2000; MAGALHÃES et al.,1996; CITADIN et al., 2010; SASSO et al., 2010). Os frutos também são aproveitados pela indústria farmacêutica e alimentícia, em consequência do seu alto teor de substâncias antioxidantes. $\mathrm{O}$ uso das jabuticabeiras como planta ornamental também é indicado devido à exuberância e beleza da florada e frutificação (CITADIN et al., 2010).

Segundo Borges e Melo (2013) a madeira da jabuticabeira é resistente e pode ser destinada ao preparo de vigas, esteios, dormentes e outras obras internas. A jabuticabeira possui ainda as seguintes indicações fitoterápicas: antiasmática, inflamação das amídalas, inflamação dos intestinos, hemoptise, erisipela, e esquinência crônica (BORGES; MELO, 2013).

A jabuticaba apresenta um grande potencial de consumo devido as suas características sensoriais. Segundo Citadin et al. (2010), a comercialização da jabuticaba no Brasil tem aumentado anualmente. Foram comercializadas, no ano de 2008, aproximadamente 2.000 toneladas de jabuticabas nos entrepostos da CEAGESP (Companhia de Entrepostos e Armazéns Gerais de São Paulo) e CEASAS (Curitiba e Belo Horizonte). A comercialização, em algumas regiões do país, é feita principalmente na forma in natura às margens de rodovias, por famílias carentes que coletam os frutos de plantas nativas, gerando uma atividade informal de importância econômica e social, sendo esta responsável por proporcionar renda adicional a essas famílias durante o período de colheita da fruta (CITADIN et al., 2010).

Apesar desse reconhecido potencial de comercialização, o cultivo em escala comercial é considerado pouco explorado e limitado a determinadas regiões. Em sedes de propriedades rurais como, chácaras, sítios ou fazendas, compõe os pomares de forma peculiar (SATO; CUNHA, 2007; CITADIN et al., 2010).

Embora popular em todo o país, a jabuticaba não chega a ter valor comercial muito elevado, por ser muito perecível, mas tem sua venda garantida. Apesar de ser grande a produção de um único pé, depois de colhida, a fruta por ter uma vida útil limitada (dois a três dias), tem sua comercialização prejudicada (LIMA et al, 2008) 
A produção poderá ser ampliada e alastrar-se por novos mercados, desde que se invista em pesquisa básica e tecnológica sobre técnicas de cultivo e manejo pós-colheita desta fruta. (DANNER et al., 2006; CITADIN et al., 2010).

\subsection{Legislação para bebidas}

O Decreto $\mathrm{n}^{\circ}$ 6.871, de 4 de junho de 2009, regulamenta a Lei $\mathrm{n}^{\mathrm{o}} 8.918$, de 14 de julho de 1994, que dispõe sobre a padronização, a classificação, o registro, a inspeção, a produção e a fiscalização de bebidas. $\mathrm{O}$ mesmo define bebida como:

I-bebida: o produto de origem vegetal industrializado, destinado à ingestão humana em estado líquido, sem finalidade medicamentosa ou terapêutica;

II - também bebida: a polpa de fruta, o xarope sem finalidade medicamentosa ou terapêutica, os preparados sólidos e líquidos para bebida, a soda e os fermentados alcoólicos de origem animal, os destilados alcoólicos de origem animal e as bebidas elaboradas com a mistura de substâncias de origem vegetal e animal.

As bebidas serão classificadas segundo o artigo 12, do referido decreto em:

I - bebida não alcoólica: é a bebida com graduação alcoólica até meio por cento em volume, a vinte graus Celsius, de álcool etílico potável, a saber:

a) bebida não fermentada não alcoólica; ou

b) bebida fermentada não alcoólica;

II - bebida alcoólica: é a bebida com graduação alcoólica acima de meio por cento em volume até cinquenta e quatro por cento em volume, a vinte graus Celsius. 


\subsubsection{Bebidas não alcóolicas}

\section{a) Suco}

O artigo 18 define Suco ou sumo como a bebida não fermentada, não concentrada, ressalvados os casos a seguir especificados, e não diluída, destinada ao consumo, obtida da fruta madura e sã, ou parte do vegetal de origem, por processamento tecnológico adequado, submetida a tratamento que assegure a sua apresentação e conservação até o momento do consumo (Brasil, 2009).

\section{b) Refresco}

$\mathrm{O}$ artigo 22 define refresco ou bebida de fruta ou de vegetal como a "bebida não fermentada, obtida pela diluição, em água potável, do suco de fruta, polpa ou extrato vegetal de sua origem, com ou sem adição de açúcares” (Brasil, 2009).

$\S 1^{1^{\circ}}$ Quando adicionado de dióxido de carbono, o refresco ou bebida de fruta ou de vegetal será denominado "refresco ou bebida de ...", acrescido do nome da fruta ou do vegetal, gaseificado.

$\S 2^{\mathrm{o}}$ Os refrescos de laranja ou laranjada, de tangerina e de uva deverão conter no mínimo trinta por cento em volume de suco natural.

$\S 3^{0} \mathrm{O}$ refresco de limão ou limonada deverá conter no mínimo cinco por cento em volume de suco de limão.

$\S 4^{\underline{0}}$ O refresco de maracujá deverá conter no mínimo seis por cento em volume de suco de maracujá.

$\S 5^{\circ} \mathrm{O}$ refresco, quando adicionado de açúcares, deverá ter a designação adoçado acrescida à sua denominação. 
$\S 6^{\circ} \mathrm{O}$ refresco de guaraná deverá conter no mínimo dois centésimos de grama da semente de guaraná (gênero Paullinia) ou seu equivalente em extrato, na bebida, por cem mililitros da bebida.

$\S 7^{0}$ O refresco de maçã deverá conter no mínimo vinte por cento em volume em suco de maçã.

$\S 8^{0}$ Refresco misto ou bebida mista de frutas, de extratos vegetais ou de frutas e extratos vegetais é a bebida obtida pela diluição em água potável da mistura de suco de fruta, da mistura de extrato vegetal, ou pela combinação de ambos.

\section{c) Néctar}

O artigo 21 define néctar como a bebida não fermentada, obtida da diluição em água potável da parte comestível do vegetal ou de seu extrato, adicionado de açúcares, destinada ao consumo direto (Brasil, 2009).

$\S 1^{\text {o }}$ Quando adicionado de dióxido de carbono, o néctar será denominado "néctar de ...", acrescido do nome da fruta ou vegetal, gaseificado.

$\S 2^{-}$Néctar misto é a bebida obtida da diluição em água potável da mistura de partes comestíveis de vegetais, de seus extratos ou combinação de ambos, e adicionado de açúcares, destinada ao consumo direto.

\section{d) Xarope}

O artigo 26 define xarope como o "produto não gaseificado, obtido pela dissolução, em água potável, de suco de fruta, polpa ou parte do vegetal e açúcar, em concentração mínima de cinqüenta e dois por cento de açúcares, em peso, a vinte graus Celsius" (Brasil, 2009). 
$\S 1^{0}$ Xarope de suco ou squash é o produto que contiver, no mínimo, quarenta por cento do suco de fruta ou polpa, em peso.

$\S 2^{0}$ Xarope de avenca ou capilé é o produto que contiver suco de avenca, aromatizado com essência natural de frutas, podendo ser colorido com caramelo.

$\S 3^{\circ}$ Xarope de amêndoa ou orchata é o produto que contiver amêndoa, adicionado de extrato de flores de laranjeira.

$\S 4^{0}$ Xarope de guaraná é o produto que contiver, no mínimo, dois décimos de grama de semente de guaraná (gênero Paullinia), ou seu equivalente em extrato, por cem mililitros do produto.

$\S 5^{\mathrm{o}}$ Não será permitida a adição de edulcorantes hipocalóricos e não-calóricos na fabricação de xarope.

$\S 6^{-} \mathrm{O}$ xarope que não contiver a matéria-prima de origem vegetal será denominado de xarope artificial.

\subsection{Valor energético de bebidas}

Na prática é muito usada uma unidade de calor (energia), muito antiga, a caloria. Por definição, uma caloria (1 cal) é a quantidade de calor que deve ser transferida a um grama de água para produzir a variação de temperatura de $1^{\circ} \mathrm{C}$, rigorosamente, de $14,5^{\circ} \mathrm{C}$ para $15,5^{\circ} \mathrm{C}$, sendo assim uma caloria corresponde a 4,186 Joule) (UFRGS, 2014). A Agência Nacional de Vigilância Sanitária (ANVISA) define caloria como sendo a energia proveniente dos alimentos que o nosso corpo utiliza para a manutenção da vida e reprodução. As calorias são calculadas a partir da quantidade de gorduras, proteínas e carboidratos presentes nos alimentos (BRASIL, 2003).

O Joule é a unidade tradicionalmente usada para medir energia, ou seja, uma medida da capacidade de realizar trabalho. Apesar do valor energético ou calórico dos alimentos serem expressos em calorias, o Joule (J) é a unidade utilizada pelo Sistema Internacional de Medidas (ATKINS; JONES, 2006). 
São três as formas de se determinar o valor energético de um alimento. Duas dessas formas são através da utilização de tabelas de composição química, sendo que a primeira é feita por meio da formulação do produto (lista de ingredientes e quantidade dos mesmos), ou seja, é necessária a composição química de cada ingrediente do alimento. A segunda forma calcula diretamente através o valor energético da composição química do produto pronto, não sendo necessária a formulação do produto. A terceira forma de confeccionar a tabela de informação nutricional para os valores energéticos é através de laudos de laboratórios, sendo necessária uma análise físicoquímica do produto (QUEIROZ, 2005).

\subsection{Análise sensorial}

A análise sensorial é realizada em função das respostas transmitidas pelos indivíduos às várias sensações que se originam de reações fisiológicas e são resultantes de certos estímulos, gerando a interpretação das propriedades inerentes aos produtos. Para isto é preciso que haja entre os indivíduos e produtos, contato e interação. $\mathrm{O}$ estímulo é medido por processos físicos e químicos e as sensações por efeitos psicológicos. As sensações produzidas podem dimensionar a intensidade, extensão, duração, qualidade, gosto ou desgosto em relação ao produto avaliado. Nesta avaliação, os indivíduos, por meio dos próprios órgãos sensórios, numa percepção somato-sensorial, utilizam os sentidos da visão, olfato, audição, tato e gosto (BRASIL, 2005).

Segundo ABNT (1993), a análise sensorial é essencial para medir e interpretar as reações produzidas pelas características dos alimentos e a forma como são percebidas pelos sentidos humanos.

Testes afetivos são métodos utilizados em análises sensoriais de alimentos, bebidas e água. $\mathrm{O}$ julgador expressa seu estado emocional ou reação afetiva ao escolher um produto pelo outro. É a forma usual de se medir a opinião de um grande número de consumidores com respeito as suas preferências, gostos e opiniões. As escalas mais empregadas são: de intensidade, a hedônica, do ideal e de atitude ou de intenção. Os julgadores não precisam ser treinados bastando ser consumidores frequentes do produto em avaliação. Os testes afetivos em função do local de aplicação podem ser de laboratório, localização central e uso doméstico. Os testes afetivos podem ser classificados em duas categorias: de preferência (escolha) e de aceitação (categoria) (BRASIL, 2005). 
Com o teste da escala hedônica, o indivíduo expressa o grau de gostar ou de desgostar de um determinado produto, de forma globalizada ou em relação a um atributo específico. As escalas mais utilizadas são as de 7 e 9 pontos, que contêm os termos definidos situados, por exemplo, entre "gostei muitíssimo" e "desgostei muitíssimo", contendo um ponto intermediário com o termo "nem gostei; nem desgostei". É importante que as escalas possuam número balanceado de categorias para gosto e desgosto. As amostras codificadas com algarismos de três dígitos e aleatorizadas são apresentadas ao julgador para avaliar o quanto gosta ou desgosta de cada uma delas através da escala previamente definida. Sua preferência é obtida por inferência. Os dados coletados podem ser avaliados estatisticamente pela análise de variância, ANOVA e comparação das médias de pares de amostras pelo teste de Tukey. Se for empregada escala hedônica com comparação a um padrão de referência, será utilizado o teste de Dunnett. Recomenda-se que o número de julgadores para os testes em laboratório seja entre 50 e 100. O delineamento experimental a ser utilizado deve ser previamente escolhido, podendo-se optar pelo de blocos completos balanceados ou casualizados ou blocos incompletos casualizados, conforme a situação (BRASIL, 2005). 


\section{MATERIAL E MÉTODOS}

O trabalho experimental foi realizado no Laboratório de Bebidas do Departamento de Horticultura, da Faculdade de Ciências Agronômicas, UNESP, Campus de Botucatu, no período de novembro de 2011 a dezembro de 2013.

\subsection{Material}

A matéria-prima utilizada para a elaboração tanto do xarope como do refresco adoçado de jabuticaba foram frutos de jabuticabeira da espécie Sabará, colhidas em novembro de 2012 em propriedade rural localizada na região centro-oeste do Estado de São Paulo.

Após a colheita, os frutos foram selecionados, utilizando-se somente os maduros, inteiros e sem imperfeições na casca, os quais foram lavados três vezes em água corrente, posteriormente colocadas sobre peneira para drenar o excesso de 
água e então congelados em freezer doméstico à temperatura média de $-15^{\circ} \mathrm{C}$ para posterior utilização.

O agente adoçante utilizado foi o açúcar tipo cristal da marca comercial Santa Isabel. Como diluente utilizou-se água potável duplamente filtrada em filtros de celulose e carvão ativo.

A operação de extração a quente do extrato aquoso de jabuticaba foi realizada por aquecimento direto em fogão doméstico a gás. Também foram utilizados, durante o processo, materiais como: caldeirão de aço inoxidável, peneira de aço inoxidável, tecido sintético de poliéster (voil), assim como vidrarias de uso regular para as análises laboratoriais.

\subsection{Métodos}

\subsubsection{Delineamento experimental}

A pesquisa foi dividida em duas etapas.

Na primeira foram avaliados dois métodos de extração de sólidos solúveis dos frutos denominados:

Extração 1: extração dos sólidos solúveis de jabuticaba esmagada, em solução aquosa em proporção 1:1(m/m), a quente.

Extração 2: extração dos sólidos solúveis de jabuticaba inteira em solução aquosa em proporção 1:1(m/m), a quente.

A partir de cada um dos processos de extração foi elaborado o xarope a $60^{\circ}$ Brix, que originou três tipos de refrescos adoçados preparados com diferentes concentrações de sólidos solúveis $\left(10,12\right.$, e $14^{\circ}$ Brix $)$, tanto para o tratamento de extração 1 como para o tratamento de extração 2, totalizando 6 diferentes tratamentos, com três repetições cada um, compondo 18 parcelas experimentais conforme descrito na Tabela 3. 
Tabela 3. Tratamentos realizados na etapa 1 do projeto.

Teor de sólidos solúveis dos refrescos adoçados de jabuticaba

$10^{\circ}$ Brix

$\mathrm{T} 1$

$\mathrm{T} 4$ $12^{\circ}$ Brix

T2

T5 $14^{\circ}$ Brix

T3

T6

A segunda etapa foi desenvolvida utilizando-se o método de extração com frutos inteiros. O critério para esta definição foi baseado nos resultados das análises físico-químicas e sensoriais.

Após a extração foram produzidos xaropes com concentração de sólidos solúveis diferentes $\left(60\right.$ e $70^{\circ}$ Brix $)$ do qual originaram refrescos adoçados de jabuticaba a $12^{\circ}$ Brix.

Nesta etapa os refrescos obtidos foram avaliados físico-químico, e sensorialmente, cujo delineamento é descrito a seguir:

Tratamento 1: Xarope com concentração de sólidos solúveis a $60^{\circ}$ Brix e diluição do xarope para a produção de refresco adoçado de jabuticaba com concentração de sólidos solúveis a $12^{\circ}$ Brix.

Tratamento 2: Xarope com concentração de sólidos solúveis a $70^{\circ}$ Brix e diluição do xarope para a produção de refresco adoçado de jabuticaba com concentração de sólidos solúveis a $12^{\circ}$ Brix.

\subsubsection{Processamento}

\subsubsection{Etapa 1}

a) Colheita e beneficiamento 
As jabuticabas maduras foram colhidas manualmente em um pomar de uma propriedade rural na cidade de Itapuí/SP e transportadas para o laboratório onde foi realizado uma pré-limpeza para retirar os galhos, folhas, pedúnculos, frutas deterioradas e insetos (Figura 2). Em seguida, as frutas foram selecionadas de acordo com a maturação e posteriormente lavadas três vezes em água corrente e colocadas sobre peneira para drenar o excesso de água (Figura 3).

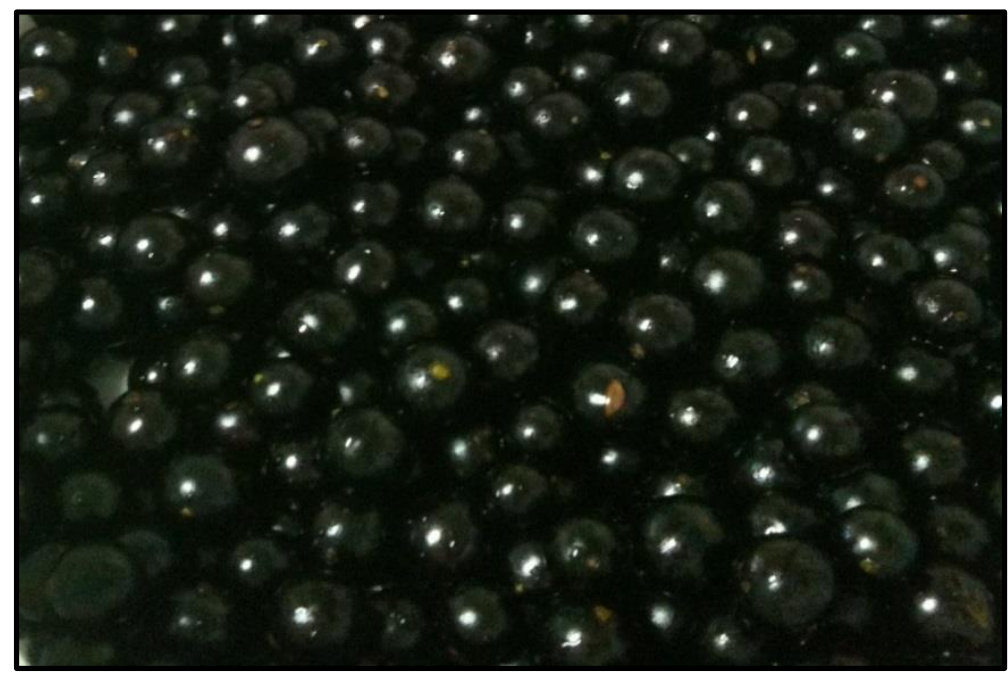

Figura 2. Jabuticabas Sabará in natura.

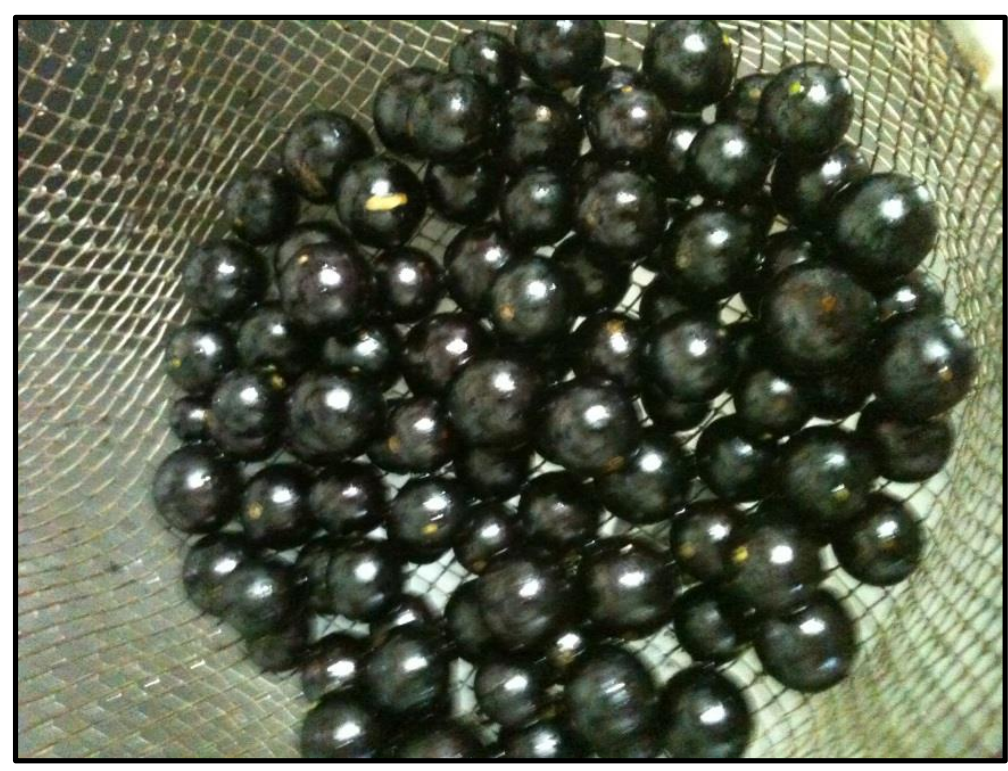

Figura 3. Etapa de drenagem do excesso de água. 


\section{b) Obtenção dos extratos aquosos de jabuticaba}

Extracão 1 (jabuticaba esmagada): uma quantidade prédeterminada de jabuticaba foi pesada (em béqueres de vidro) e esmagada com as mãos. A mesma quantidade de água (massa) foi adicionada ao fruto esmagado (Figura 4). Partindo de 1,5 (kg) de jabuticaba, adicionou-se 1,5 (kg) de água filtrada. A mistura foi transferida para uma panela de aço inoxidável e aquecida em fogo direto mantendo-se a fervura por 10 minutos (Figura 5). Ressalta-se que o tempo de fervura foi definido a partir de pré-testes onde considerou-se como parâmetro o rendimento, o tempo e temperatura da operação em questão. Em seguida, a mistura ainda morna, foi filtrada em tecido sintético de poliéster (voil) de malha fina para a separação do líquido em relação ao bagaço (Figura 7).

Extracão 2 (jabuticaba inteira): realizada nas mesmas condições da extração 1, porém utilizando-se os frutos inteiros.

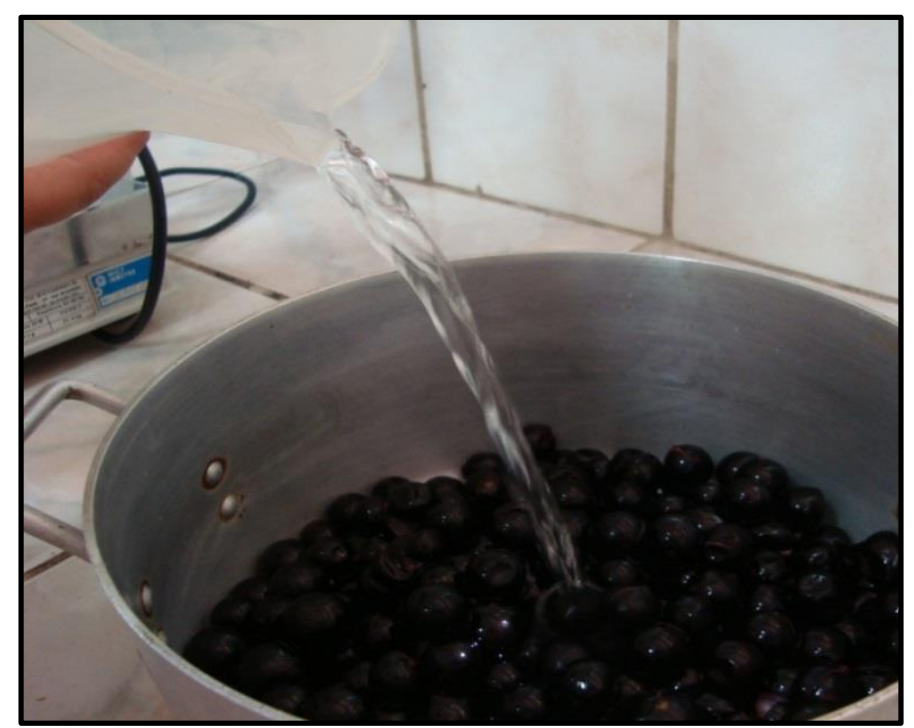

Figura 4. Acréscimo de água filtrada ao fruto. 


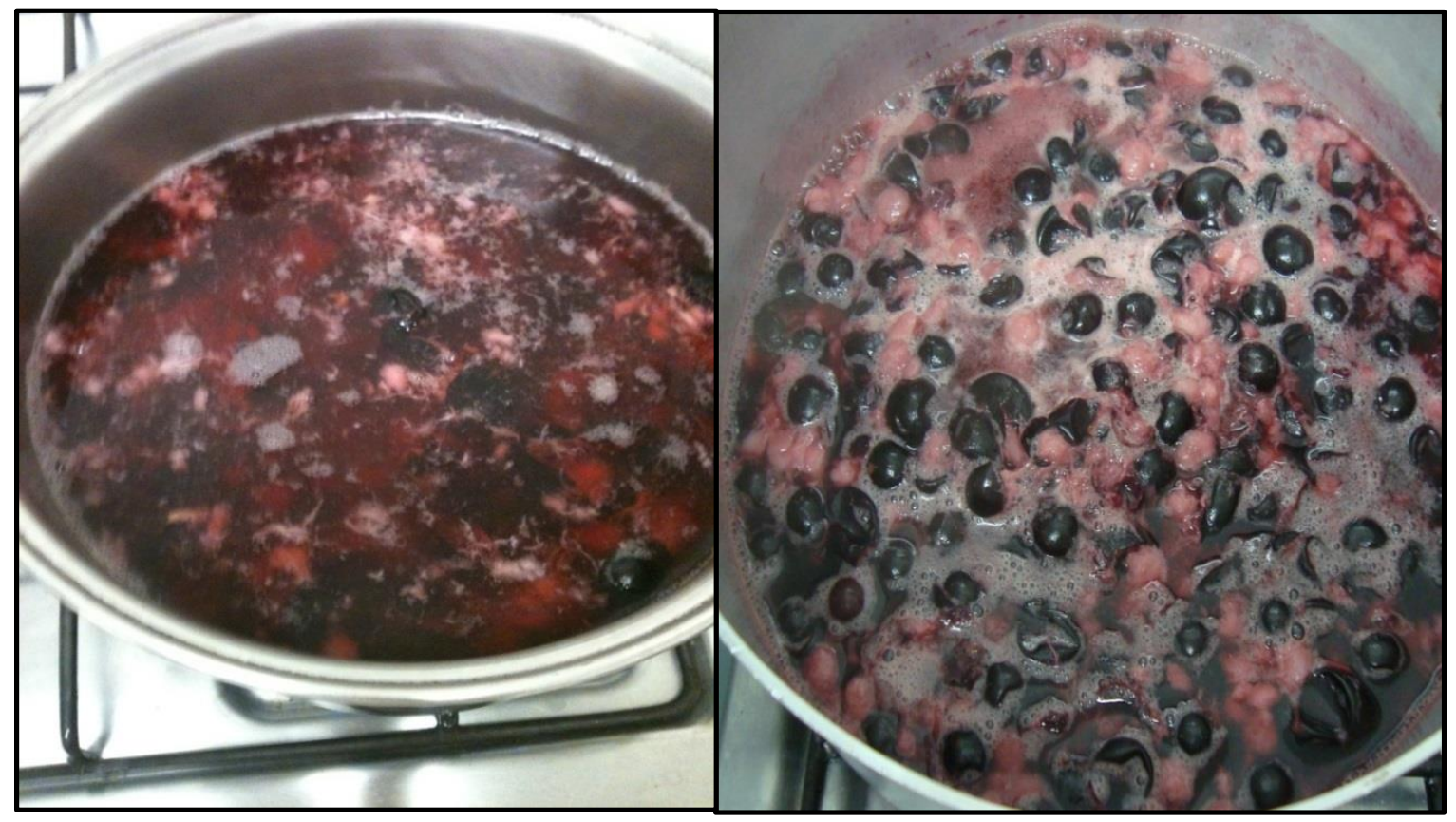

Figura 5. Aquecimento em fogo direto da mistura (jabuticaba esmagada com água filtrada).

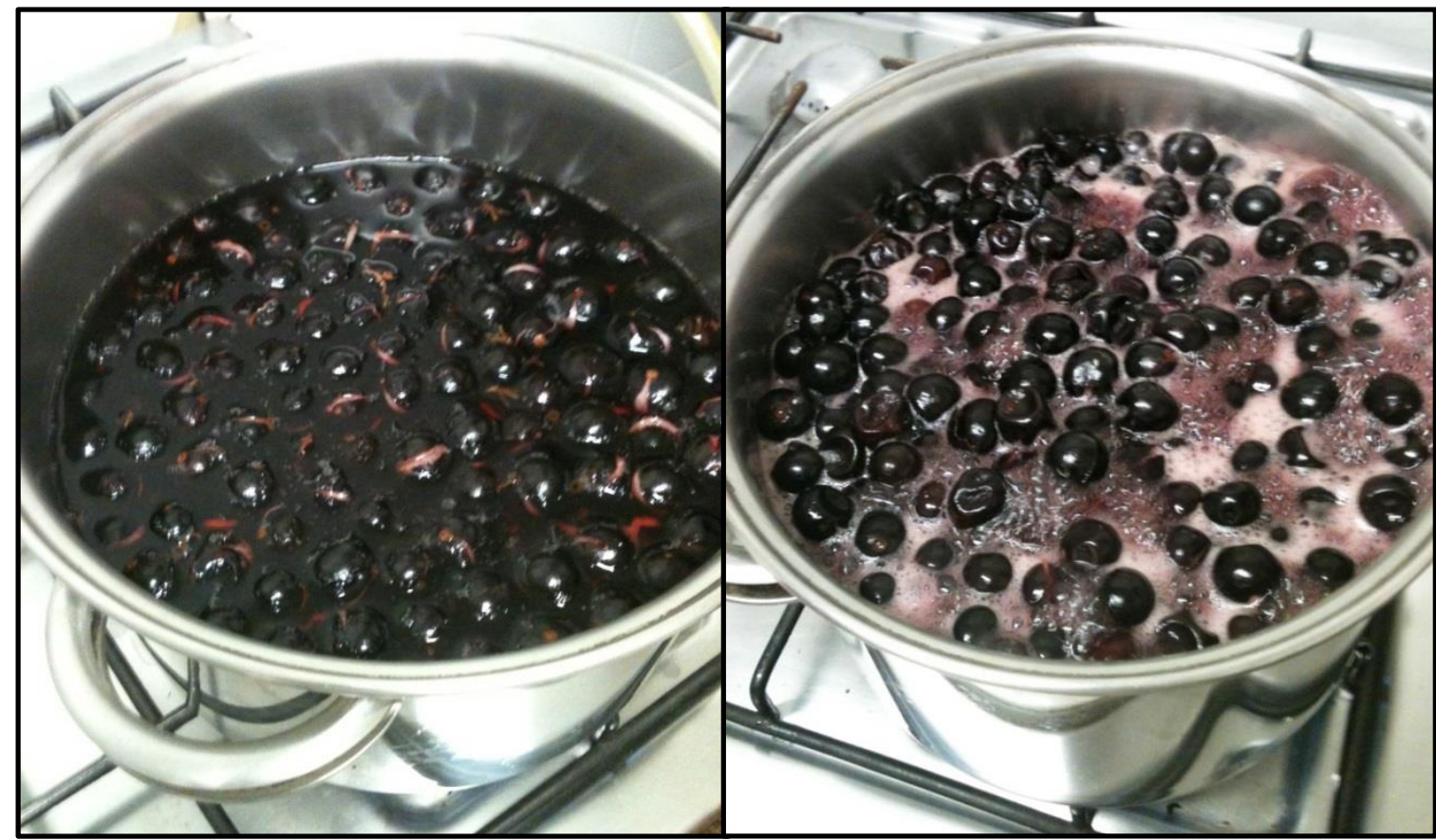

Figura 6. Aquecimento em fogo direto da mistura (jabuticaba inteira com água filtrada). 


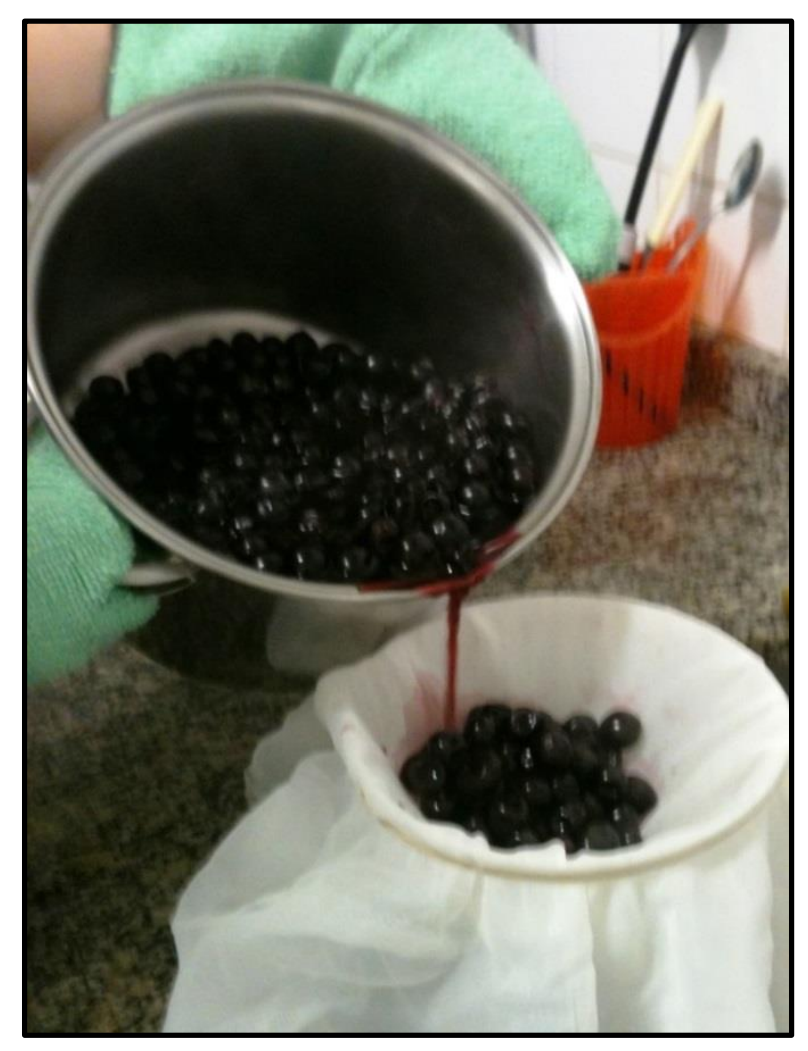

Figura 7. Filtração em voil para separação do extrato e do bagaço.

\section{c) Elaboração do xarope}

Para a preparação dos xaropes, os caldos resultantes das extrações 1 e 2 tiveram o teor de sólidos solúveis padronizado para $60^{\circ}$ Brix, por meio da adição de açúcar cristal. O cálculo da quantidade de açúcar utilizado foi realizado através da equação 1.

$$
B_{1} \cdot M_{1}+B_{2} \cdot M_{2}=B_{3} \cdot M_{3}
$$

Onde:

$\mathrm{B}_{1}=$ Brix do caldo extraído

$\mathrm{M}_{1}=$ Massa do caldo extraído

$\mathrm{B}_{2}=$ Brix do açúcar cristal $\left(100^{\circ}\right.$ Brix $)$ 
$\mathrm{M}_{2}=$ massa do açúcar cristal

$\mathrm{B}_{3}=$ Brix do xarope $\left(60^{\circ}\right.$ Brix $)$

$\mathrm{M}_{3}=$ massa do xarope

Os xaropes produzidos foram acondicionados à quente em garrafas de vidro verde transparente de 1,5 litros (Figura 8), fechadas com tampas de plástico rosqueáveis, e mantidas na temperatura de refrigeração $\left(5 \pm 1^{\circ} \mathrm{C}\right)$ até o momento do uso.

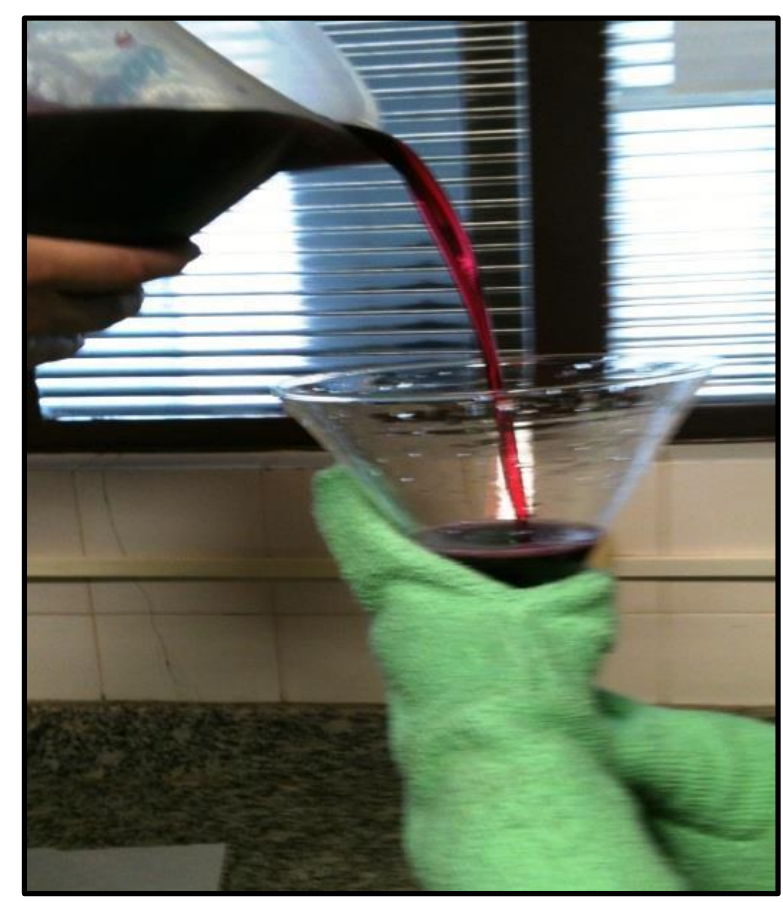

Figura 8. Acondicionamento do xarope em garrafas de vidro.

\section{d) Elaboração do refresco adoçado de jabuticaba}

Os refrescos adoçados de jabuticaba, com concentração de sólidos solúveis iguais a 10,12 e $14^{\circ}$ Brix, foram obtidos a partir da diluição do xarope $\left(60^{\circ}\right.$ Brix $)$ com água duplamente filtrada (celulose e carvão ativo). O cálculo da quantidade de água e xarope necessário para fazer as diluições foi efetuado através de balanço de massa (Equação 2).

$$
B_{1} \cdot M_{1}+B_{2} \cdot M_{2}=B_{3} \cdot M_{3}
$$


Onde:

$\mathrm{B}_{1}=$ Brix do xarope $\left(60^{\circ}\right.$ Brix $)$

$\mathrm{M}_{1}=$ Massa do xarope

$\mathrm{B}_{2}=$ Brix da água $\left(0^{\circ}\right.$ Brix $)$

$\mathrm{M}_{2}=$ Massa da água

$\mathrm{B}_{3}=$ Brix do refresco $\left(10,12,14^{\circ} \mathrm{Brix}\right)$

$\mathrm{M}_{3}=$ Massa do refresco

Os refrescos adoçados de jabuticaba foram acondicionados à quente em garrafas de vidro branco transparente de $500 \mathrm{~mL}$, lacradas com tampas metálicas rosqueáveis e mantidas na temperatura de congelamento $\left(-15^{\circ} \mathrm{C}\right)$ até o momento da realização das determinações físico-químicas e energéticas. Para análise sensorial os refrescos foram preparados com 24 horas de antecedência e mantidos em refrigeração $\left(5 \pm 1^{\circ} \mathrm{C}\right)$, até a realização dos testes sensoriais.

Todas as operações descritas estão apresentadas no fluxograma da Figura 9. 


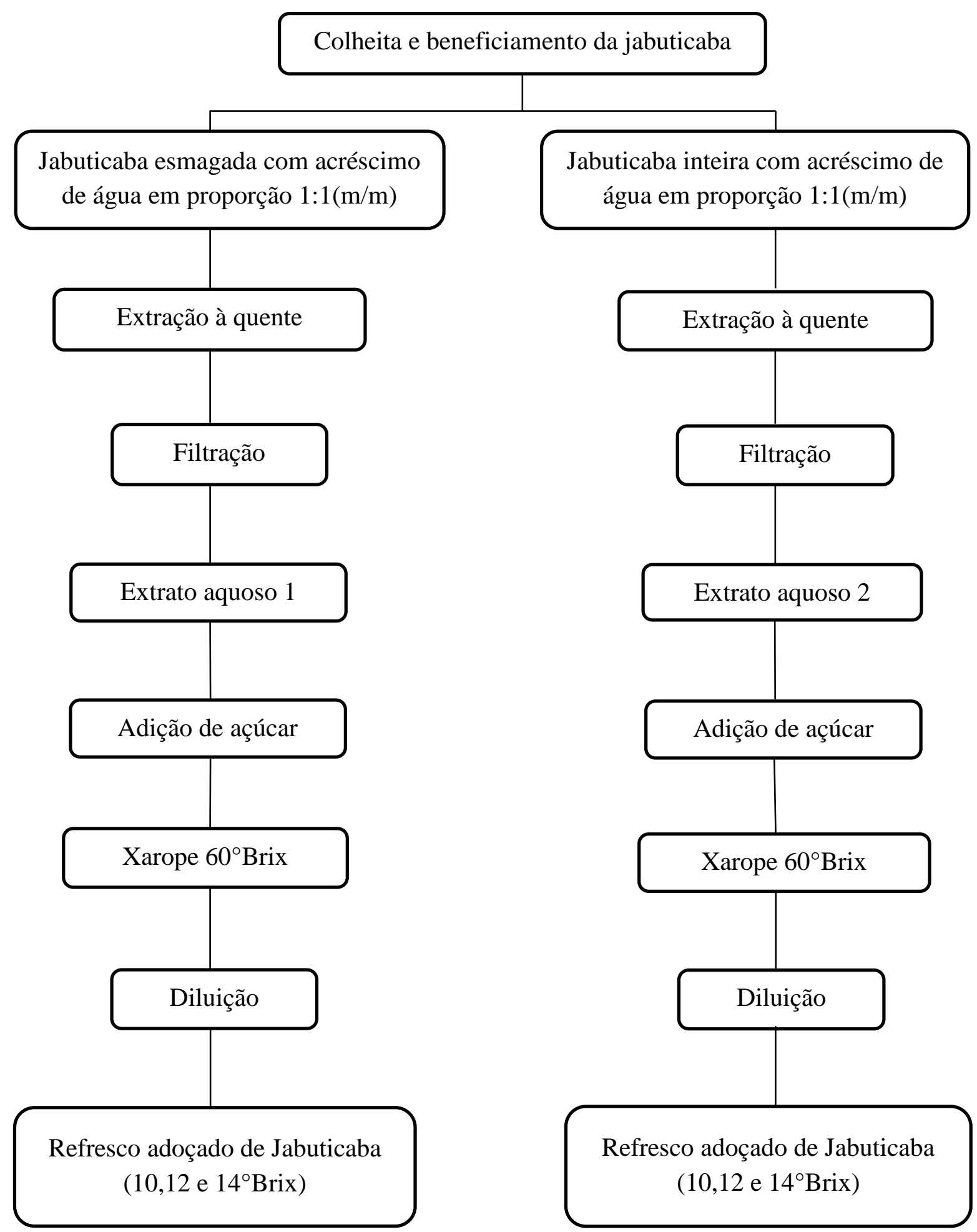

Figura 9. Fluxograma do processamento na etapa 1. 


\subsubsection{Etapa 2}

Os frutos foram colhidos e beneficiados da mesma maneira como descrito na etapa 1.

a) Obtenção dos extratos aquosos de jabuticaba

A metodologia de obtenção do extrato aquoso usado nesta etapa foi descrita anteriormente no item b da primeira etapa a partir de frutos inteiros (extração 2).

\section{b) Preparação do xarope}

Para a preparação do xarope, o caldo resultante da extração teve o teor de sólidos solúveis corrigido para 60 e $70^{\circ}$ Brix, por meio da adição de açúcar cristal. O cálculo da quantidade de açúcar adicionada foi efetuado por meio da Equação 2, descrita no item d da primeira etapa.

O xarope produzido foi acondicionado à quente em garrafas de vidro verde transparente de 1,5 litros, vedadas com tampas de plástico rosqueáveis, e mantidas sob refrigeração $\left(5 \pm 1^{\circ} \mathrm{C}\right)$, até o momento do uso.

\section{c) Elaboração do refresco adoçado de jabuticaba}

Os refrescos adoçados de jabuticaba a $12^{\circ}$ Brix foram elaborados a partir da diluição dos xaropes $\left(60\right.$ e $70^{\circ}$ Brix $)$ com água duplamente filtrada em filtro de celulose e carvão ativo. O cálculo da quantidade de água foi efetuado através de balanço de massa (Equação 3) para determinar as quantidades de xarope e água que deveriam ser usados.

Os refrescos adoçados de jabuticaba foram acondicionados em garrafas de vidro branco transparente de $500 \mathrm{~mL}$, vedadas com tampas metálicas rosqueáveis e mantidas na temperatura de congelamento $\left(-15^{\circ} \mathrm{C}\right)$ para posterior realização das análises físico-químicas e energéticas. Os refrescos utilizados nas análises sensoriais 
foram elaborados com um dia de antecedência e mantidos em refrigeração $\left(5 \pm 1^{\circ} \mathrm{C}\right)$, até o momento da realização dos testes sensoriais.

Todas as operações descritas estão apresentadas no fluxograma da Figura 10.

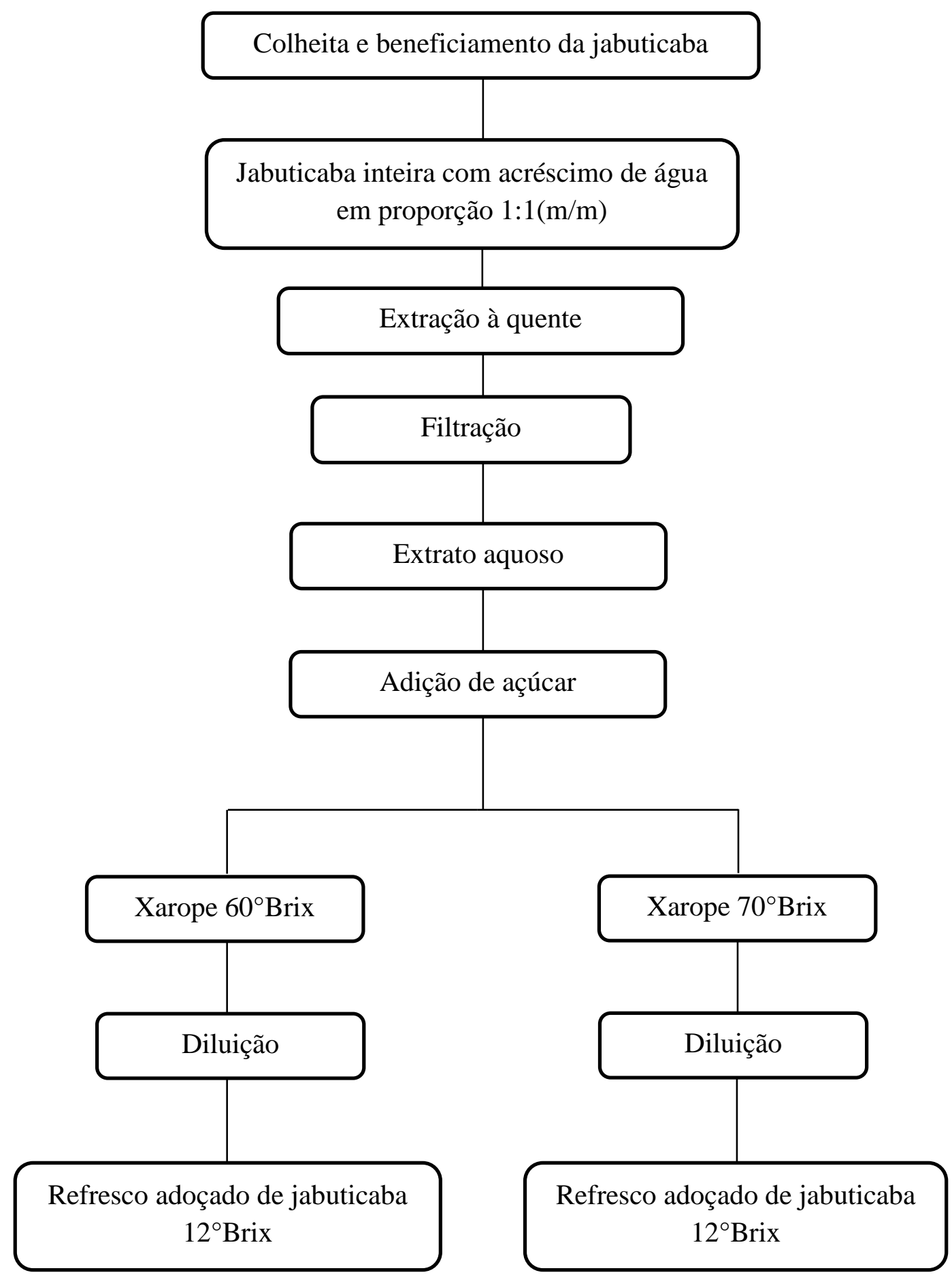

Figura 10. Fluxograma do processamento na etapa 2. 


\section{d) Cálculo do teor de fruta nos xaropes}

O teor de fruta presente nos xaropes foi calculado por meio da equação 3.

Teor de fruta $=\frac{\text { Massa de sólidos solúveis do extrato aquoso de jabuticaba }}{\text { Massa sólidos solúveis do xarope }} * 100$

\subsubsection{Análises físico-químicas}

Os refrescos adoçados de jabuticaba foram analisados em triplicata em relação ao teor de sólidos solúveis $\left({ }^{\circ} \mathrm{Brix}\right), \mathrm{pH}$, acidez titulável, ratio, açúcares redutores (AR), açúcares redutores totais (ART) , turbidez, cinzas, umidade, proteínas, lipídeos totais e carboidratos.

- Sólidos solúveis

Os refrescos adoçados de jabuticaba foram analisados quanto aos sólidos solúveis em refratômetro digital de bancada, marca Reichert, modelo $\mathrm{r}^{2} \mathrm{i} 3000$;

- $\mathbf{p H}$

A leitura do $\mathrm{pH}$ foi realizada em pHmetro digital de bancada (Micronal; modelo TEC-5) conforme método 017/IV de Brasil (2005), para amostras líquidas. Pesou-se $10 \mathrm{~g}$ da amostra em um béquer e diluiu com auxílio de $100 \mathrm{~mL}$ de água sob agitação. Determinou-se o pH, com o aparelho previamente calibrado, operando-o de acordo com as instruções do manual do fabricante. 
- Acidez Titulável

Para determinar a acidez titulável, foram adicionados $10 \mathrm{~mL}$ de amostra em $100 \mathrm{~mL}$ de água destilada em um béquer de $200 \mathrm{~mL}$. Esta solução foi mantida sob agitação enquanto procedeu-se a titulação com hidróxido de sódio $(\mathrm{NaOH}) 0,1 \mathrm{~N}$ até a faixa de $\mathrm{pH}$ entre 8,2 a 8,4; segundo metodologia 311/IV, de Brasil (2005).

Os resultados obtidos foram convertidos para g de ácido cítrico 100 $\mathrm{g}^{-1}$ de amostra, conforme método 312/IV, de Brasil (2005).

- Ratio

É a razão entre os sólidos solúveis, expressos em ${ }^{\circ}$ Brix, e acidez titulável. Para este cálculo foi utilizado o método 316/IV de Brasil (2005). Os resultados desta análise são adimensionais.

$$
\text { Ratio }=\text { Brix / acidez titulável }
$$

\section{- Açúcares redutores (AR)}

Os açúcares redutores (AR) foram determinados conforme o método de Lane-Eynon, usando solução de Fehling, utilizando metodologia adaptada de COPERSUCAR (2001). O resultado foi expresso em gramas de glicose $100 \mathrm{~mL}^{-1}$.

\section{- Açúcares redutores totais (ART)}

Após a hidrólise, a quantificação foi realizada pelo método de AR, citado anteriormente utilizando a metodologia adaptada de COPERSUCAR (2001). A inversão da sacarose foi realizada por hidrólise ácida $\left(\mathrm{HCl}, 65^{\circ} \mathrm{C}, 30\right.$ minutos $)$. 
- Turbidez

Os refrescos adoçados de jabuticaba foram analisados quanto à turbidez em turbidímetro de bancada, marca Hach, modelo 2100N, seguindo instruções de uso do aparelho. Os valores obtidos foram expressos em Unidades Nefelométricas de Turbidez (NTU).

- Umidade

O teor de umidade foi determinado pelo método de secagem em estufa através da perda de peso da amostra, quando aquecida a $105 \pm 1{ }^{\circ} \mathrm{C}$ até peso constante (BRASIL, 2005).

- Cinzas

O teor de cinzas foi determinado pela incineração em mufla a $550^{\circ} \mathrm{C}$ até as cinzas estarem brancas ou levemente acinzentadas. O método utilizado foi 018/IV de Brasil (2005).

- Lipídio

Os teores de lipídios foram determinados pelo método de extração com solvente e purificação, proposto por Bligh e Dyer (1959).

- Proteína

O teor de proteína bruta foi determinado a partir do teor de nitrogênio total, usando fator 6,25, pelo método Kjeldahl modificado (BRASIL, 2005).

- Carboidrato

O teor de carboidrato foi calculado pela diferença entre 100 e a soma das porcentagens de água, proteínas, lipídios totais e cinzas (BRASIL, 2011). 


\subsubsection{Análise energética}

As frações da composição centesimal (umidade, extrato etéreo, proteínas, carboidratos e cinzas) foram quantificadas através das metodologias descritas por Brasil (2005).

Conforme normas da legislação brasileira (BRASIL, 2003), o valor energético deve ser expresso em kcal e kJ nos rótulos dos produtos. Assim, os valores energéticos obtidos em kcal foram convertidos para kJ (1kcal equivale a 4,186kJ).

Esses valores foram calculados a partir da concentração de proteína, lipídio, carboidrato, utilizando os fatores energéticos de conversão.

- Proteína: 4 kcal . $100 \mathrm{~g}^{-1}$;

- Lipídio: $9 \mathrm{kcal} .100 \mathrm{~g}^{-1}$;

- Carboidrato: 3,75 kcal . $100 \mathrm{~g}^{-1}$;

$$
\mathrm{VE}=\mathrm{FC} \cdot \mathrm{CN}
$$

Onde:

$\mathrm{VE}=$ valor energético $\left(\mathrm{kcal} .100 \mathrm{~g}^{-1}\right)$;

$\mathrm{FC}=$ fator de conversão específico $\left(\mathrm{kcal} \cdot \mathrm{g}^{-1}\right)$;

$\mathrm{CN}=$ concentração do componente nutricional na bebida $\left(\mathrm{g} .100 \mathrm{~g}^{-1}\right)$

\subsubsection{Análise sensorial}

Os refrescos adoçados de jabuticaba foram avaliados sensorialmente por meio de testes afetivos. Aplicou-se o teste de aceitação utilizando escala hedônica estruturada de nove pontos, ancorada pelas notas 1 "desgostei muitíssimo" a nota 9 "gostei muitíssimo". Foram avaliados os seguintes atributos: aparência (cor e turbidez), aroma, sabor e avaliação global. (BRASIL, 2005).

A equipe foi composta por 60 provadores não selecionados e não treinados de ambos os sexos, na faixa etária de 18 a 50 anos. Os provadores foram recrutados entre os alunos dos cursos de graduação em Agronomia e pós-graduação em 
Agronomia-Energia na Agricultura da UNESP-Campus de Botucatu. Para cada provador, foram servidos $50 \mathrm{~mL}$ dos refrescos na temperatura de refrigeração $\left(5 \pm 1^{\circ} \mathrm{C}\right)$, em taças de vidros brancos e transparentes (BRASIL, 2005).

As análises sensoriais dos refrescos adoçados de jabuticaba foram realizadas sob luz branca e as amostras foram codificadas com algarismos de três dígitos, servidas aleatoriamente em taças de vidro, à temperatura de refrigeração. A ficha de modelo do teste de escala hedônica é mostrada na Figura 10.

As análises sensoriais realizadas foram aprovadas pelo comitê de ética em pesquisa como apresentado no apêndice.

Nome:

Data:

Você esta recebendo duas amostras codificadas de refresco adoçado de jabuticaba. Por favor, prove-as da esquerda para a direita e avalie o quanto você gostou ou desgostou da mesma, utilizando a escala abaixo.

9. gostei muitíssimo

4. desgostei ligeiramente

8. gostei muito

3. desgostei moderadamente

7. gostei moderadamente

2. desgostei muito

6. gostei ligeiramente

1. desgostei muitíssimo

5. não gostei/nem desgostei

$\begin{array}{lllll}\text { Amostra } & \text { Aparência } & \text { Aroma } & \text { Sabor } & \text { Avaliação Global } \\ & - & & & \\ & & & & \end{array}$

Comentário:

Figura 11. Ficha modelo do teste de escala hedônica.

\subsubsection{Análises estatísticas}

Na primeira etapa o delineamento experimental, fatorial $2 \times 3$, foi inteiramente casualizado, os resultados das análises físico-químicas e sensoriais foram avaliados estatisticamente por análise de variância (ANOVA) e teste de Tukey (5\% de probabilidade). 
$\mathrm{Na}$ segunda etapa o delineamento experimental foi inteiramente casualizado, os resultados das análises físico-químicas e sensoriais foram avaliados estatisticamente por análise de variância (ANOVA) e teste t (5\% de probabilidade). 


\section{RESULTADOS E DISCUSSÃO}

\subsection{Etapa 1}

\subsubsection{Análises físico-químicas}

O método de extração, a concentração de sólidos solúveis e a interação desses fatores interferiram nas variáveis físicas (turbidez) e químicas ( ${ }^{\circ}$ Brix, acidez total, AR e cálculo do ratio) de todas as amostras das bebidas elaboradas neste experimento, com exceção dos valores de pH e ART, conforme apresentado na Tabela 4. 
Tabela 4. Significâncias estatísticas obtidas pelo teste F para as análises físico-químicas realizadas nos refrescos adoçados de jabuticaba.

\begin{tabular}{|c|c|c|c|}
\hline Parâmetros & Tipo extração & $\begin{array}{c}\text { Teor de Sólidos } \\
\text { Solúveis }\end{array}$ & Interação \\
\hline $\mathrm{pH}$ & $* *$ & $* *$ & ns \\
\hline Sólidos Solúveis $\left({ }^{\circ} \mathrm{Brix}\right)$ & $* *$ & $* *$ & $*$ \\
\hline $\begin{array}{c}\text { Acidez Total } \\
\text { (g de ác. Cítrico } .100 \mathrm{~mL}^{-1} \text { ) }\end{array}$ & $* *$ & $* *$ & * \\
\hline Ratio & $* *$ & $* *$ & $* *$ \\
\hline Turbidez (NTU) & $* *$ & $* *$ & $*$ \\
\hline $\operatorname{AR}\left(\mathrm{g} .100 \mathrm{~mL}^{-1}\right)$ & $* *$ & $* *$ & $* *$ \\
\hline $\operatorname{ART}\left(\mathrm{g} .100 \mathrm{~mL}^{-1}\right)$ & $\mathrm{ns}$ & $* *$ & $\mathrm{~ns}$ \\
\hline
\end{tabular}

Teste F: * significativo ao nível de $5 \%$ de probabilidade $(0,01 \leq \mathrm{p}<0,05) ; * *$ significativo ao nível de $1 \%$ de probabilidade $(\mathrm{p}<0,01)$, ns não significativo $(\mathrm{p} \geq 0,05)$.

Mediante os resultados da Tabela 5, observou-se que o método de extração interferiu diretamente nas médias dos valores de $\mathrm{pH}$, de 3,98 $\pm 0,10$ nos refrescos obtidos pela extração com frutos inteiros e de 3,75 $\pm 0,08$ e nos refrescos obtidos pela extração com frutos esmagados, com diferença estatística significativa. Pereira et al. (2000) obtiveram resultados semelhantes aos do presente estudo, em relação aos valores de $\mathrm{pH}$, para o fruto inteiro de jabuticaba que foi de 3,8 , enquanto os do presente estudo variaram de 3,70 $\pm 0,05$ a 4,05 $\pm 0,10$, demonstrando que os refrescos adoçados de jabuticaba desenvolvidos experimentalmente mantêm as características do fruto.

Segundo Cecchi (2003) a acidez é uma variável importante, pois os ácidos orgânicos presentes em alimentos influenciam o sabor, odor, cor, estabilidade e a manutenção de qualidade, além de que a acidez total em relação ao conteúdo de açúcar é útil na determinação da maturação da fruta. A acidez total de frutas varia de 0,2 a 0,3\% em frutos de baixa acidez, 2\% em ameixas e acima de 6\% em limão (CECCHI, 2003).

Os teores de acidez total variaram de 0,027 a 0,069 g de ácido cítrico . $100 \mathrm{~mL}^{-1}$ em todos os tratamentos avaliados e diferiram estatisticamente entre as médias em relação ao tipo de extração e teores de sólidos solúveis dos refrescos $(10,12$ e 
$14^{\circ}$ Brix), conforme Tabela 5. Estes valores podem ser considerados baixos quando comparados aos obtidos por Oliveira et al. (2003) que caracterizou frutos inteiros de jabuticabas provenientes de várias regiões de cultivo, apresentando valores de acidez total que variam de 0,888 a $1,652 \mathrm{~g}$ ácido cítrico. $100 \mathrm{~g}^{-1}$ de polpa.

Os refrescos adoçados de jabuticaba, que utilizaram a fruta inteira na sua formulação, apresentaram valores de $\mathrm{pH}$ mais altos e uma diminuição nos valores de acidez total, quando comparados aos refrescos adoçados de jabuticaba, que utilizaram o fruto esmagado na sua formulação, os quais apresentaram uma diminuição dos valores de $\mathrm{pH}$ e um aumento nos valores de acidez. Portanto, pode-se observar que o rompimento da casca favoreceu a liberação de ácidos orgânicos, presumíveis responsáveis pelo aumento nos valores de acidez total.

Segundo Chitarra e Chitarra (2005), o ratio, relação de sólidos solúveis/acidez, é uma das formas mais utilizadas para a avaliação do sabor dos frutos, sendo mais representativa que a medição isolada de açúcares ou da acidez.

Em relação à extração, a redução dos valores de ratio nas bebidas elaboradas com jabuticabas esmagadas está associada à acidez mais elevada, quando comparada com bebidas formuladas com os frutos inteiros.

Os valores de turbidez, apresentados na Tabela 5 foram diretamente proporcionais à concentração de açúcar nas bebidas elaboradas. A sacarose pura não confere turbidez, mas o açúcar cristal apresenta outros componentes além da sacarose que conferem esta característica, como por exemplo: dextrana, amido, partículas de bagaço, gomas e ceras da cana-de-açúcar (OLIVEIRA, 2006). A turbidez também foi alterada conforme o método de extração, ou seja, formulações do refresco que utilizaram jabuticaba esmagada apresentaram as maiores médias de turbidez. Isso ocorreu, pois a jabuticaba esmagada libera mais componentes de alto peso molecular (proteínas, pectinas e outras gomas e ceras) que conferem turbidez às bebidas.

As médias dos teores de açúcares redutores expressos em g.100 $\mathrm{mL}^{-1}$ apresentaram diferenças em relação ao tipo de extração, pois o esmagamento da jabuticaba favoreceu a liberação de açúcares redutores proporcionando assim valores maiores em relação as médias quantificadas nos refrescos que utilizaram a jabuticaba inteira. Os valores de açúcares redutores aumentaram à medida que os teores de sólidos solúveis eram maiores, ou seja, indicando a ocorrência do início da hidrólise da sacarose. 
Os valores de açúcares redutores totais aumentaram conforme o ocorrido com os teores de sólidos solúveis e de açúcares redutores, corroborando com o resultado esperado diante da quantidade de sacarose utilizada nas formulações dos diferentes refrescos de jabuticaba elaborados (Tabela 5).

Tabela 5. Médias das variáveis físico-químicas, seguidas do desvio padrão, dos refrescos adoçados de jabuticaba.

\begin{tabular}{ccccc}
\hline $\begin{array}{c}\text { Tipo de } \\
\text { Extração }\end{array}$ & $10^{\circ}$ Brix & $12^{\circ}$ Brix & $14^{\circ}$ Brix & Média \\
\hline Inteira & $4,05 \pm 0,10$ & $3,97 \pm 0,09$ & $3,94 \pm 0,085$ & $3,98 \pm 0,10^{\mathbf{a}}$ \\
\hline Esmagada & $3,80 \pm 0,09$ & $3,76 \pm 0,07$ & $3,70 \pm 0,05$ & $3,75 \pm 0,08^{\mathbf{b}}$ \\
\hline Média & $3,93 \pm 0,16^{\mathbf{A}}$ & $3,87 \pm 0,13^{\mathbf{A B}}$ & $3,82 \pm 0,14^{\mathbf{B}}$ & C.V. $(\%) 2,13$ \\
\hline Inteira & $0,027 \pm 0,003^{\mathbf{b C}}$ & $0,042 \pm 0,006^{\mathbf{b B}}$ & $0,056 \pm 0,003^{\mathbf{b A}}$ & $0,042 \pm 0,012^{\mathbf{b}}$ \\
\hline Esmagada & $0,047 \pm 0,003^{\mathbf{a C}}$ & $0,059 \pm 0,003^{\mathbf{a B}}$ & $0,069 \pm 0,004^{\mathbf{a A}}$ & $0,058 \pm 0,009^{\mathbf{a}}$ \\
\hline Média & $0,037 \pm 0,01^{\mathbf{C}}$ & $0,050 \pm 0,009^{\mathbf{B}}$ & $0,062 \pm 0,007^{\mathbf{A}}$ & C.V. $(\%) 8,19$ \\
\hline
\end{tabular}

\section{Sólidos Solúveis $\left({ }^{0} \mathrm{Brix}\right)$}

\begin{tabular}{lcccc}
\hline Inteira & $9,92 \pm 0,16^{\mathbf{b C}}$ & $12,07 \pm 0,05^{\mathbf{a B}}$ & $14,02 \pm 0,10^{\mathbf{a A}}$ & $12,00 \pm 1,71^{\mathbf{b}}$ \\
Esmagada & $10,11 \pm 0,09^{\mathbf{a C}}$ & $12,10 \pm 1,88^{\mathbf{a B}}$ & $14,04 \pm 0,12^{\mathbf{a A}}$ & $12,09 \pm 1,64^{\mathbf{a}}$ \\
\hline Média & $10,02 \pm 0,16^{\mathbf{C}}$ & $12,08 \pm 0,04^{\mathbf{B}}$ & $14,03 \pm 0,11^{\mathbf{A}}$ & C.V. (\%) 0,83 \\
\hline $\begin{array}{l}\text { *Médias de três repetições } \pm \text { desvio padrão. Médias seguidas da mesma letra minúscula na coluna e } \\
\text { maiúscula na linha não diferem entre si pelo teste de Tukey a } 5 \% \text { de probabilidade. C.V.: coeficiente de } \\
\text { variação. }\end{array}$
\end{tabular}


Tabela 5. Continuação.

\section{Ratio}

\begin{tabular}{|c|c|c|c|c|}
\hline Inteira & $368 \pm 47,11^{\text {aA }}$ & $288 \pm 37,70^{\mathbf{a B}}$ & $249 \pm 13,61^{\mathrm{aC}}$ & $302 \pm 61,24^{\mathbf{a}}$ \\
\hline Esmagada & $216 \pm 15,55^{\mathbf{b A}}$ & $204 \pm 11,34^{\mathbf{b A}}$ & $204 \pm 12,72^{\mathbf{b A}}$ & $208 \pm 13,91^{\mathbf{b}}$ \\
\hline Média & $292 \pm 85,64^{\mathbf{A}}$ & $246 \pm 50,83^{\mathbf{B}}$ & $226 \pm 26,28^{\mathbf{B}}$ & C.V. (\%) 10,57 \\
\hline \multicolumn{5}{|c|}{ Turbidez (NTU) } \\
\hline Inteira & $46,17 \pm 2,84^{\mathrm{aA}}$ & $44,17 \pm 4,70^{\mathbf{b A}}$ & $48,55 \pm 4,26^{\mathbf{b A}}$ & $46,30 \pm 4,26^{\mathbf{b}}$ \\
\hline Esmagada & $44,62 \pm 4,60^{\mathbf{a B}}$ & $49,72 \pm 5,09^{\mathbf{a A B}}$ & $54,49 \pm 5,22^{\text {aA }}$ & $49,61 \pm 6,30^{\mathrm{a}}$ \\
\hline Média & $45,39 \pm 3,79^{\mathbf{B}}$ & $46,94 \pm 5,54^{\mathbf{B}}$ & $51,52 \pm 5,54^{\mathbf{A}}$ & C.V. (\%) 9,42 \\
\hline \multicolumn{5}{|c|}{$\operatorname{AR}\left(\mathrm{g} \cdot 100 \mathrm{~mL}^{-1}\right)$} \\
\hline Inteira & $4,29 \pm 0,15^{\mathbf{b C}}$ & $4,95 \pm 0,30^{\mathbf{b B}}$ & $5,49 \pm 0,12^{\mathbf{b A}}$ & $4,91 \pm 0,54^{\mathbf{b}}$ \\
\hline Esmagada & $4,74 \pm 0,15^{\mathrm{aC}}$ & $5,37 \pm 0,13^{\mathbf{a B}}$ & $6,40 \pm 0,26^{\mathbf{a A}}$ & $5,51 \pm 0,72^{\mathrm{a}}$ \\
\hline Média & $4,52 \pm 0,27^{\mathrm{C}}$ & $5,16 \pm 0,31^{\mathbf{B}}$ & $5,95 \pm 0,50^{\mathbf{A}}$ & C.V. $(\%) 3,82$ \\
\hline
\end{tabular}

$\operatorname{ART}\left(\mathrm{g} \cdot 100 \mathrm{~mL}^{-1}\right)$

\begin{tabular}{lccrc}
\hline Inteira & $111,17 \pm 3,06$ & $128,94 \pm 7,25$ & $154,40 \pm 4,53$ & $131,50 \pm 18,70$ \\
Esmagada & $111,05 \pm 3,45$ & $121,18 \pm 34,88$ & $147,63 \pm 5,06$ & $126,62 \pm 25,27$ \\
\hline Média & $111,11 \pm 3,19^{\text {C }}$ & $125,06 \pm 24,95^{\text {B }}$ & $151,01 \pm 5,83^{\text {A }}$ & C.V. (\%) 11,57 \\
\hline $\begin{array}{l}\text { *Médias de três repetições } \pm \text { desvio padrão. Médias seguidas da mesma letra minúscula na coluna e } \\
\text { maiúscula na linha não diferem entre si pelo teste de Tukey a 5\% de probabilidade. C.V.: coeficiente de } \\
\text { variação. }\end{array}$
\end{tabular}




\subsubsection{Composição centesimal e valor energético}

A composição dos alimentos é essencial para obter a segurança alimentar e nutricional. As informações de uma tabela de composição de alimentos são fundamentais para a educação alimentar, para o controle da qualidade dos alimentos bem como a avaliação da ingestão de nutrientes de uma população. Através dela, é possível formular a rotulagem nutricional com o objetivo de auxiliar consumidores na escolha dos alimentos, além de permitir às autoridades de saúde pública estabelecer metas nutricionais e guias alimentares que induzam a uma dieta mais saudável (BRASIL, 2011).

O teor de sólidos solúveis foi significativo em relação às variáveis energéticas avaliadas como umidade, lipídio, carboidratos e proteínas, exceto para a variável cinzas, conforme apresentado na Tabela 6. O método de extração interferiu significativamente apenas nas variáveis lipídios e proteínas.

Tabela 6. Significâncias estatísticas obtidas pelo teste F para a composição centesimal e valores energéticos dos refrescos adoçados de jabuticaba.

\begin{tabular}{cccc}
\hline Parâmetros & Tipo de extração & $\begin{array}{c}\text { Teor de Sólidos } \\
\text { Solúveis }\end{array}$ & Interação \\
\hline Umidade & $\mathrm{ns}$ & $* *$ & $\mathrm{~ns}$ \\
Cinzas & $\mathrm{ns}$ & $\mathrm{ns}$ & $\mathrm{ns}$ \\
Proteína & $* *$ & $* *$ & $* *$ \\
Lipídios & $* *$ & $* *$ & $* *$ \\
Carboidratos & $\mathrm{ns}$ & $* *$ & $\mathrm{~ns}$ \\
Valor Energético & $\mathrm{ns}$ & $* *$ & $* *$ \\
\hline
\end{tabular}

Teste $\mathrm{F}:{ }^{* *}$ significativo ao nível de $1 \%$ de probabilidade $(\mathrm{p}<0,01)$, ns não significativo $(\mathrm{p} \geq 0,05)$.

Todos os alimentos, qualquer que seja o método de industrialização a que tenham sido submetidos, contêm água em maior ou menor proporção. Geralmente a 
umidade representa a água contida no alimento, que pode ser classificada em: umidade de superfície, que se refere à água livre ou presente na superfície externa do alimento, facilmente evaporada e umidade adsorvida, referente à água ligada, encontrada no interior do alimento, sem combinar-se quimicamente com o mesmo (BRASIL, 2005).

Os teores de umidade, expressos em percentagem do refresco elaborado variam de 85,63 a 89,90\%. Lima et al. (2008) encontraram teores de umidade em frutos inteiros de jabuticaba Sabará em torno de 79\%. Portanto, constatou-se que por se tratar de uma bebida diluída e elaborada por meio da extração do suco da fruta, os teores de umidade são mais elevados no produto quando comparados à fruta in natura.

Cinzas é o nome dado ao resíduo obtido por aquecimento de um produto em temperatura próxima a $(550-570)^{\circ} \mathrm{C}$, esse resíduo representa toda a substância inorgânica presente na amostra, mas nem sempre isso ocorre, pois alguns sais podem sofrer redução ou volatilização durante o aquecimento (BRASIL, 2005).

Os teores de cinzas apresentadas na Tabela 7 variaram entre as médias dos tratamentos de 0,017 a $0,033 \%$. Comparando-se as médias de cinzas dos refrescos avaliados com teores de cinzas avaliados em frutos inteiros da espécie Sabará, Lima et al. (2008) obtiveram valores em torno de 3,82\%. Deste modo, como se trata de um produto elaborado a partir de um extrato diluído da jabuticaba, os teores de cinzas no presente estudo são menores em comparação a frutos in natura como o esperado.

Os teores de proteína, quando comparados em relação aos teores de sólidos solúveis dos refrescos elaborados, ao método de extração e a interação desses fatores apresentaram valores significativos, cujas médias variaram de 0,28 a 1,19 \% (Tabela 7), valores próximos aos encontrados por Lima et al. (2008) que variaram de $0,47 \%$, na polpa do fruto, a 1,16\% presente na casca de jabuticabas Sabará. Ressalta-se que as médias obtidas pelo método de extração com frutos esmagados foram significativamente maiores em relação ao método de extração com frutos inteiros. Os valores médios de proteína aumentaram concomitantemente em relação aos teores de sólidos.

Em todos os tratamentos avaliados as médias de lipídios dos refrescos elaborados foram maiores no método de extração que utilizou frutos inteiros na sua formulação sendo de 0,38 \%. Em comparação aos resultados apresentados por Lima et al. (2008),em jabuticabas Sabará, a fração da casca apresentou média de 0,57\%, da polpa $0,06 \%$ e do fruto inteiro $0,42 \%$. 
Os carboidratos são os componentes mais abundantes e largamente distribuídos entre os alimentos. Sua determinação nos alimentos é importante, pois apresentam várias funções tais como nutricional, adoçantes naturais, matéria-prima para produtos fermentados, principal ingrediente dos cereais, propriedades reológicas dos alimentos de origem vegetal e é responsável pela reação de escurecimento em muitos alimentos (CECCHI, 2003).

O teor de sólidos solúveis influenciou significativamente os teores de carboidrato dos refrescos adoçados de jabuticaba que variaram de 9,42 a 13,86\%. Os teores de carboidratos aumentaram proporcionalmente em relação ao aumento do teor de sólidos solúveis das bebidas elaboradas como apresentados na Tabela 7. Os carboidratos presentes nos refrescos adoçados de jabuticaba são basicamente sacarose, frutose e glicose, representadas por parte dos sólidos solúveis extraídos da fruta mais os teores de sacarose adicionados ao xarope.

Tabela 7. Valores médios da composição centesimal e do valor energético dos refrescos adoçados de jabuticaba.

\begin{tabular}{ccccc}
\hline $\begin{array}{c}\text { Tipo de } \\
\text { Extração }\end{array}$ & $10^{\circ}$ Brix & $12^{\circ}$ Brix & $14^{\circ}$ Brix & Média \\
\hline Inteira & 89,90 & Umidade (\%) & 87,73 \\
Esmagada & 89,85 & 87,94 & 85,65 & 87,81 \\
\hline Média & $89,88^{\mathbf{A}}$ & $87,80^{\mathbf{B}}$ & 85,63 & $85,64{ }^{\mathbf{C}}$ \\
\hline Inteira & 0,027 & Cinzas $(\%)$ & & C.V. $(\%) 0,41$ \\
\hline Esmagada & 0,017 & 0,024 & 0,033 & 0,028 \\
\hline Média & 0,022 & 0,028 & 0,024 & 0,023 \\
\hline
\end{tabular}

*Médias de três repetições. Médias seguidas da mesma letra minúscula na coluna e maiúscula na linha não diferem entre si pelo teste de Tukey a 5\% de probabilidade. C.V.: coeficiente de variação. 
Tabela 7. Continuação.

\section{Proteína (\%)}

\begin{tabular}{|c|c|c|c|c|}
\hline Inteira & $0,37^{\text {aA }}$ & $0,28^{\mathbf{b A}}$ & $0,33^{\mathbf{b A}}$ & $0,33^{\mathbf{b}}$ \\
\hline Esmagada & $0,30^{\mathbf{a C}}$ & $0,63^{\mathrm{aB}}$ & $1,19^{\mathbf{a A}}$ & $0,71^{a}$ \\
\hline Média & $0,34^{\mathbf{B}}$ & $0,46^{\mathbf{B}}$ & $0,76^{\mathbf{A}}$ & C.V. (\%) 29,88 \\
\hline \multicolumn{5}{|c|}{ Lipídio (\%) } \\
\hline Inteira & $0,33^{\mathbf{a B}}$ & $0,70^{\mathbf{a A}}$ & $0,13^{\mathrm{aB}}$ & $0,38^{\mathbf{a}}$ \\
\hline Esmagada & $0,33^{\text {aA }}$ & $0,20^{\mathbf{b A B}}$ & $0,12^{\mathrm{aB}}$ & $0,22^{\mathbf{b}}$ \\
\hline Média & $0,33^{\mathbf{A}}$ & $0,45^{\mathbf{A}}$ & $0,12^{\mathbf{B}}$ & C.V. (\%) 49,91 \\
\hline \multicolumn{5}{|c|}{ Carboidratos (\%) } \\
\hline Inteira & 9,42 & 11,39 & 13,86 & 11,56 \\
\hline Esmagada & 9,49 & 11,18 & 13,15 & 11,27 \\
\hline Média & $9,45^{\mathrm{C}}$ & $11,29^{\mathbf{B}}$ & $13,50^{\mathrm{A}}$ & C.V. $(\%) 4,17$ \\
\hline \multicolumn{5}{|c|}{ Valor Energético (kcal) } \\
\hline Inteira & $39,75^{\mathrm{aC}}$ & $50,12^{\mathbf{a B}}$ & $54,43^{\text {aA }}$ & 48,10 \\
\hline Esmagada & $39,79^{\mathrm{aC}}$ & $46,31^{\mathbf{b B}}$ & $55,13^{\mathbf{a A}}$ & 47,08 \\
\hline Média & $39,77^{\mathrm{C}}$ & $48,22^{\mathbf{B}}$ & $54,78^{\mathrm{A}}$ & C.V. (\%) 3,80 \\
\hline \multicolumn{5}{|c|}{ Valor Energético (kJ) } \\
\hline Inteira & $166,40^{\mathrm{aC}}$ & $209,82^{\mathbf{a B}}$ & $227,82^{\mathbf{a A}}$ & 201,35 \\
\hline Esmagada & $166,55^{\mathrm{aC}}$ & $193,87^{\mathbf{b B}}$ & $230,76^{\text {aA }}$ & 197,06 \\
\hline Média & $166,48^{\mathrm{C}}$ & $201,84^{\text {B }}$ & $229,29^{\mathbf{A}}$ & C.V. $(\%) 3,80$ \\
\hline
\end{tabular}

*Médias de três repetições. Médias seguidas da mesma letra minúscula na coluna e maiúscula na linha não diferem entre si pelo teste de Tukey a 5\% de probabilidade. C.V.: coeficiente de variação. 


\subsubsection{Análise sensorial}

Todos os refrescos foram avaliados sensorialmente aplicando-se o teste afetivo de aceitação. Foram analisados os atributos aparência, aroma, sabor e avaliação global. Os resultados, apresentados nas Tabelas 8 e 9, mostraram que não ocorreu diferença significativa entre as amostras de refresco em relação ao método de extração utilizado para a composição do xarope. Porém verificou-se que ocorreu diferença significativa ao nível de $1 \%$ de probabilidade quanto à concentração de sólidos solúveis presente nos refrescos $\left(10,12\right.$ e $14^{\circ}$ Brix $)$ para todos os atributos em questão.

Tabela 8. Significâncias estatísticas obtidas pelo teste $\mathrm{F}$ para as análises sensoriais realizadas nos refrescos de jabuticaba.

\begin{tabular}{cccc}
\hline Parâmetros & Tipo extração & $\begin{array}{c}\text { Teor de Sólidos } \\
\text { Solúveis }\end{array}$ & Interação \\
\hline Aparência & $\mathrm{ns}$ & $* *$ & $\mathrm{~ns}$ \\
Aroma & $\mathrm{ns}$ & $* *$ & $\mathrm{~ns}$ \\
Sabor & $\mathrm{ns}$ & $* *$ & $\mathrm{~ns}$ \\
Avaliação Global & $\mathrm{ns}$ & $* *$ & $\mathrm{~ns}$ \\
\hline
\end{tabular}

Teste $\mathrm{F}$ : ** significativo ao nível de $1 \%$ de probabilidade $(\mathrm{p}<0,01)$, ns não significativo $(\mathrm{p} \geq 0,05)$.

O teor de sólidos solúveis interferiu significativamente na aparência das bebidas. Os valores das notas para o atributo aparência variaram de 6,15 a 7,20 (entre "gostei ligeiramente" e "gostei moderadamente" na escala hedônica), cujos refrescos adoçados de jabuticaba com maior teor de sólidos solúveis apresentaram as maiores notas de avaliação para a aparência. Isso corrobora com a coloração mais intensa das bebidas.

As médias das notas para o atributo aroma aumentaram conforme o aumento do teor de sólidos solúveis dos refrescos, ou seja, variaram de 5,53 a 6,32 (entre "não gostei/nem desgostei” e "gostei ligeiramente" na escala hedônica) nos refrescos de 10 e $14^{\circ}$ Brix, respectivamente. Portanto nos refrescos com maior ${ }^{\circ}$ Brix, ou seja, maior concentração de fruta, o aroma das bebidas foi percebido mais claramente pelos provadores. Segundo os provadores, houve dificuldade para percepção do aroma dos refrescos produzidos. 
Tabela 9. Comparação de médias das notas, seguidas do desvio padrão, dos atributos sensoriais aparência, aroma, sabor e avaliação global dos refrescos de jabuticaba.

\begin{tabular}{|c|c|c|c|c|}
\hline \multirow{2}{*}{$\begin{array}{c}\text { Tipo de } \\
\text { Extração }\end{array}$} & \multicolumn{4}{|c|}{ Teor de Sólidos Solúveis } \\
\hline & $10^{\circ}$ Brix & $12^{\circ}$ Brix & $14^{\circ}$ Brix & Média \\
\hline \multicolumn{5}{|c|}{ Aparência } \\
\hline Inteira & $6,15 \pm 1,54$ & $6,87 \pm 1,19$ & $7,20 \pm 1,07$ & $6,74 \pm 1,35$ \\
\hline Esmagada & $6,30 \pm 1,46$ & $6,93 \pm 1,54$ & $7,18 \pm 1,44$ & $6,81 \pm 1,52$ \\
\hline Média & $6,23 \pm 1,50^{\mathbf{B}}$ & $6,90 \pm 1,39^{\mathbf{A}}$ & $7,19 \pm 1,27^{\mathbf{A}}$ & $\begin{array}{c}\text { C.V. }(\%) \\
20,46\end{array}$ \\
\hline \multicolumn{5}{|c|}{ Aroma } \\
\hline Inteira & $5,58 \pm 1,27$ & $6,12 \pm 1,28$ & $6,32 \pm 1,47$ & $6,01 \pm 1,37$ \\
\hline Esmagada & $5,53 \pm 1,48$ & $5,88 \pm 1,54$ & $6,08 \pm 1,79$ & $5,83 \pm 1,62$ \\
\hline Média & $5,56 \pm 1,37^{\mathbf{B}}$ & $6,00 \pm 1,41^{\mathbf{A B}}$ & $6,20 \pm 1,64^{\mathbf{A}}$ & $\begin{array}{c}\text { C.V. (\%) } \\
25,04\end{array}$ \\
\hline \multicolumn{5}{|c|}{ Sabor } \\
\hline Inteira & $5,87 \pm 1,79$ & $6,60 \pm 1,43$ & $6,75 \pm 1,59$ & $6,41 \pm 1,65$ \\
\hline Esmagada & $6,00 \pm 1,85$ & $6,55 \pm 1,78$ & $6,90 \pm 1,88$ & $6,48 \pm 1,87$ \\
\hline Média & $5,93 \pm 1,81^{\mathbf{B}}$ & $6,58 \pm 1,6^{\mathbf{A}}$ & $6,83 \pm 1,7^{\mathbf{A}}$ & $\begin{array}{c}\text { C.V. }(\%) \\
26,81\end{array}$ \\
\hline \multicolumn{5}{|c|}{ Avaliação Global } \\
\hline Inteira & $5,88 \pm 1,35$ & $6,52 \pm 1,17$ & $6,75 \pm 1,45$ & $6,38 \pm 1,37$ \\
\hline Esmagada & $6,08 \pm 1,58$ & $6,45 \pm 1,60$ & $6,78 \pm 1,74$ & $6,44 \pm 1,66$ \\
\hline Média & $5,98 \pm 1,47^{\mathbf{B}}$ & $6,48 \pm 1,40^{\mathbf{A}}$ & $6,77 \pm 1,59^{\mathbf{A}}$ & $\begin{array}{c}\text { C.V. }(\%) \\
23,27\end{array}$ \\
\hline
\end{tabular}

*Médias de três repetições \pm desvio padrão. Médias seguidas da mesma letra minúscula na coluna e maiúscula na linha não diferem entre si pelo teste de Tukey a 5\% de probabilidade. C.V.: coeficiente de variação. 
O atributo sabor também apresentou relação direta quanto ao teor de sólidos solúveis dos refrescos, apresentando as maiores notas para os refrescos com maior teor de sólidos solúveis. Como sabor é uma interação de gosto (na língua) e aroma (no nariz), é provável que os refrescos adoçados de jabuticaba com maior teor de sólidos solúveis (maior concentração de fruta) apresentassem um aroma mais evidente o que favoreceu as notas para o atributo sabor. De certa forma, esse resultado confirma o resultado para o atributo aroma, pois os provadores preferem bebidas mais adocicadas (12 e $14^{\circ}$ Brix), questão de gosto, sendo que no refresco adoçado de $14^{\circ}$ Brix o aroma estava mais evidente, o que lhe atribuiu maiores médias de nota.

A avaliação global confirmou os resultados da aparência, aroma e sabor, apresentando as maiores notas para os refrescos com maior teor de sólidos solúveis.

Diante dos resultados obtidos das análises físico-químicas e sensoriais, optou-se pelo método de extração 2, com frutos inteiros, como forma de ajuste operacional, sendo esse método o mais adequado para extração de sólidos solúveis da jabuticaba. Apesar dos resultados das análises sensoriais não revelarem diferença estatística em relação ao método de extração, considerou-se as variáveis físico-químicas turbidez, acidez total, $\mathrm{pH}$, ratio como características relevantes na definição do método a ser usado para elaboração do refresco adoçado na etapa 2 deste trabalho. Além de permitir eliminar uma etapa operacional no processo tecnológico, que é o esmagamento dos frutos.

\subsection{Etapa 2}

\subsubsection{Cálculo do teor de fruta nos xaropes}

Observou-se que houve diferença significativa entre os parâmetros avaliados, conforme apresentado na Tabela 10. Os valores médios do teor de fruta e açúcar presente nos xaropes elaborados encontram-se na Tabela 11. 
Tabela 10. Significâncias estatísticas obtidas pelo teste F para os teores de fruta e açúcar presente nos xaropes elaborados.

Parâmetros

Teor de sólidos solúveis do xarope

$\left(60\right.$ e $70{ }^{\circ}$ Brix $)$

\begin{tabular}{ll}
\hline Teor de fruta $(\%)$ & $* *$ \\
Teor de açúcar $(\%)$ & $* *$ \\
\hline
\end{tabular}

Teste $\mathrm{F}$ : ** significativo ao nível de $1 \%$ de probabilidade $(\mathrm{p}<0,01)$.

Segundo os resultados contidos na Tabela 11, observa-se que o xarope de jabuticaba com concentração de sólidos solúveis de $60^{\circ}$ Brix apresenta maior teor de fruta quando comparado ao xarope com $70^{\circ}$ Brix. Da mesma forma, pode-se observar que os maiores valores, com relação ao teor de açúcar, foram encontrados nos xaropes de $70^{\circ}$ Brix, quando comparado aos xaropes de $60^{\circ}$ Brix. Portanto, os refrescos adoçados de jabuticaba, obtidos a partir da diluição do xarope de $60^{\circ}$ Brix, contêm maior teor de fruta em sua composição que os refrescos adoçados de jabuticaba obtidos da diluição do xarope de $70^{\circ}$ Brix.

Tabela 11. Médias das percentagens do teor de fruta e açúcar presente nos xaropes elaborados, seguida pelo desvio padrão.

\begin{tabular}{|c|c|c|}
\hline $\begin{array}{c}\text { Teor de sólidos solúveis } \\
\text { dos xaropes }\end{array}$ & Teor de fruta $(\%)$ & Teor de açúcar (\%) \\
\hline $60^{\circ}$ Brix & $5,69 \pm 0,17^{\mathbf{a}}$ & $94,29 \pm 0,18^{\mathbf{b}}$ \\
\hline $70^{\circ}$ Brix & $3.66 \pm 0,11^{\mathbf{b}}$ & $96,39 \pm 0,17^{\mathbf{a}}$ \\
\hline Média & $4.67 \pm 1,12$ & $95,34 \pm 1,16$ \\
\hline
\end{tabular}




\subsubsection{Análises físico-químicas}

A Tabela 12 expõe os resultados da análise estatística (ANOVA), que foi feita pelo teste $\mathrm{F}$ e as médias dos tratamentos foram comparadas entre si pelo teste $\mathrm{t}$ em nível de $5 \%$ de probabilidade.

A variação no teor de sólidos solúveis dos xaropes interferiu significativamente na maior parte dos parâmetros avaliados quanto à composição dos refrescos adoçados de jabuticaba, exceto nas variáveis turbidez e açúcar redutor total.

Tabela 12. Significâncias estatísticas obtidas pelo teste $\mathrm{F}$ para as análises físico-químicas realizadas nos refrescos adoçados de jabuticaba a $12^{\circ}$ Brix.

\section{Parâmetros}

$$
\mathrm{pH}
$$

Sólidos Solúveis $\left({ }^{\circ}\right.$ Brix $)$

Acidez Total

(g de ác. cítrico . $100 \mathrm{~mL}^{-1}$ )

Ratio

Turbidez (NTU)

$\mathrm{AR}\left(\mathrm{g} .100 \mathrm{~mL}^{-1}\right)$

$\operatorname{ART}\left(\mathrm{g} .100 \mathrm{~mL}^{-1}\right)$

\section{Teor de sólidos solúveis do xarope}

$\left(60\right.$ e $70^{\circ}$ Brix $)$

nS

Teste $\mathrm{F}$ : ** significativo ao nível de $1 \%$ de probabilidade $(\mathrm{p}<0,01)$, ns não significativo $(\mathrm{p} \geq 0,05)$.

Segundo os resultados contidos na Tabela 13, observa-se que os valores de $\mathrm{pH}$ foram maiores para a bebida com menor teor de fruta, ou seja, os refrescos produzidos a partir da diluição do xarope de $70^{\circ}$ Brix. Da mesma forma, pode-se observar que os maiores valores com relação ao parâmetro acidez total foram apresentados nas bebidas produzidas a partir da diluição do xarope de $60^{\circ}$ Brix, pois essa apresenta um teor de fruta maior em sua composição. 
Tabela 13. Médias das variáveis físico-químicas, seguidas do desvio padrão, dos refrescos adoçados de jabuticaba a $12^{\circ}$ Brix.

\section{Teor de sólidos solúveis dos xaropes}

\begin{tabular}{|c|c|c|c|}
\hline Parâmetros & $60^{\circ}$ Brix & $\mathbf{7 0}^{\circ}$ Brix & Média \\
\hline pH & $3,68 \pm 0,06^{\mathbf{b}}$ & $3,84 \pm 0,08^{\mathbf{a}}$ & $3,76 \pm 0,11$ \\
\hline Sólidos Solúveis $\left({ }^{\circ}\right.$ Brix) & $12,15 \pm 0,15^{\mathbf{b}}$ & $12,34 \pm 0,07^{\mathbf{a}}$ & $12,25 \pm 0,15$ \\
\hline $\begin{array}{c}\text { Acidez Total } \\
\text { (g de ác. cítrico } 100 \mathrm{~mL}^{-1} \text { ) }\end{array}$ & $0,061 \pm 0,004^{\mathrm{a}}$ & $0,042 \pm 0,003^{\mathbf{b}}$ & $0,052 \pm 0,010$ \\
\hline Ratio & $199 \pm 11,96^{\mathbf{b}}$ & $290 \pm 24,72^{\mathbf{a}}$ & $245 \pm 50,62$ \\
\hline Turbidez (NTU) & $36,79 \pm 3,74$ & $34,68 \pm 3,84$ & $35,73 \pm 3,84$ \\
\hline $\operatorname{AR}\left(\mathrm{g} \cdot 100 \mathrm{~mL}^{-1}\right)$ & $8,59 \pm 1,27^{\mathbf{a}}$ & $5,20 \pm 0,44^{\mathbf{b}}$ & $6,89 \pm 1,97$ \\
\hline $\operatorname{ART}\left(\mathrm{g} .100 \mathrm{~mL}^{-1}\right)$ & $114,53 \pm 7,84$ & $118,94 \pm 5,94$ & $116,73 \pm 7,17$ \\
\hline
\end{tabular}

*Médias de três repetições \pm desvio padrão. As médias seguidas pela mesma letra na linha não diferem estatisticamente entre si. Foi aplicado o Teste $\mathrm{t}$ ao nível de $5 \%$ de probabilidade.

Os valores obtidos no cálculo ratio estão de acordo com a composição do refresco, pois o único parâmetro que interferiu nos valores do ratio foi a acidez total. Portanto os refrescos que apresentaram maior teor de fruta (refrescos provenientes do xarope $60^{\circ}$ Brix) logo apresentam uma acidez maior e consequentemente valores de ratio menores. O inverso ocorre com os refrescos que apresentaram menor teor de fruta (refrescos provenientes do xarope $70^{\circ}$ Brix), como apresentam uma acidez menor os valores de ratio consequentemente são maiores.

Segundo os resultados contidos na Tabela 13, os valores de turbidez foram maiores para as bebidas produzidas a partir da diluição do xarope de $60^{\circ}$ Brix, consequência do maior teor de fruta presente nos refrescos. A hipótese mais provável é que o maior teor de acidez presente nos refrescos provindos do xarope de $60^{\circ}$ Brix fez com estes apresentassem valores de açúcares redutores (AR) maiores que os 
refrescos derivados do xarope de $70^{\circ}$ Brix, pois a maior concentração de ácidos provocou a hidrólise dos açúcares.

Os valores do parâmetro açúcar redutor total (ART) não foram significativos, pois não houve variação no teor de sólidos solúveis $\left(12^{\circ}\right.$ Brix $)$ dos refrescos adoçados.

\subsubsection{Composição centesimal e valor energético}

A diferença do teor de sólidos solúveis presente nos xaropes foi estatisticamente significativa apenas para a variável umidade, e não apresentou resultados significativos para as demais variáveis como lipídio, carboidratos, proteínas, cinzas e valor energético, conforme apresentado na Tabela 14.

Tabela 14. Significâncias estatísticas obtidas pelo teste F para a composição centesimal e valores energéticos dos refrescos adoçados de jabuticaba a $12^{\circ}$ Brix.

\begin{tabular}{cc} 
Parâmetros & $\begin{array}{c}\text { Teor de sólidos solúveis do xarope } \\
\left(\mathbf{6 0} \mathbf{~ e ~} \mathbf{7 0}^{\circ} \mathbf{B r i x}\right)\end{array}$ \\
\hline Umidade & $\mathrm{ns}$ \\
Cinzas & $\mathrm{ns}$ \\
Proteína & $\mathrm{ns}$ \\
Lipídios & $\mathrm{ns}$ \\
Carboidratos & $\mathrm{ns}$ \\
Valor Energético & \\
\hline
\end{tabular}

Teste F: ** significativo ao nível de $1 \%$ de probabilidade $(\mathrm{p}<0,01)$, ns não significativo $(\mathrm{p} \geq 0,05)$.

Os valores médios de umidade expressos em \% encontrados nos refrescos adoçados de jabuticaba foram de $87,72 \%$ nos refrescos obtidos da diluição do xarope de $60^{\circ}$ Brix e $87,64 \%$ nos refrescos obtidos da diluição do xarope de $70^{\circ}$ Brix. Valores próximos aos encontrados por Oliveira et al. (2003) em frutos inteiros de 
jabuticaba Sabará provenientes de diferentes regiões de cultivo os quais variaram de 77,8 a $84,66 \%$ de umidade.

Deve-se ressaltar que os refrescos adoçados de jabuticaba provenientes do xarope com teor de sólidos solúveis a $60^{\circ}$ Brix apresentam em sua composição maior teor de fruta o que provavelmente proporcionou as maiores médias da variável umidade quando comparado aos refrescos obtidos do xarope a $70^{\circ}$ Brix com menor teor de fruta em sua composição.

Tabela 15. Valores médios, seguidos pelo desvio padrão, da composição centesimal e do valor energético dos refrescos adoçados de jabuticaba a $12^{\circ}$ Brix.

\section{Teor de sólidos solúveis dos xaropes}

\begin{tabular}{cccc} 
Parâmetros & $\mathbf{6 0}^{\circ}$ Brix & $\mathbf{7 0}^{\circ}$ Brix & Média \\
\hline Umidade (\%) & $87,72 \pm 0,02^{\mathbf{a}}$ & $87,64 \pm 0,08$ b & $87,68 \pm 0,07$ \\
Cinzas (\%) & $0,017 \pm 0,012$ & $0,013 \pm 0,006$ & $0,015 \pm 0,009$ \\
Proteína (\%) & $0,188 \pm 0,009$ & $0,186 \pm 0,003$ & $0,187 \pm 0,006$ \\
Lipídios (\%) & $0,50 \pm 0,20$ & $0,51 \pm 0,13$ & $0,50 \pm 0,16$ \\
$\begin{array}{c}\text { Carboidratos (\%) } \\
\text { Valor Energético } \\
\text { (kcal) }\end{array}$ & $11,57 \pm 0,22$ & $11,65 \pm 0,10$ & $11,61 \pm 0,17$ \\
$\begin{array}{c}\text { Valor Energético } \\
\text { (kJ) }\end{array}$ & $48,64 \pm 0,99$ & $49,02 \pm 0,87$ & $48,83 \pm 0,91$ \\
\hline
\end{tabular}

*Médias de três repetições \pm desvio padrão. As médias seguidas pela mesma letra na linha não diferem estatisticamente entre si. Foi aplicado o Teste t ao nível de 5\% de probabilidade.

\subsubsection{Análise sensorial}

A análise sensorial é objetivada a cargo das respostas transmitidas pelos indivíduos às muitas sensações que se originam de reações fisiológicas e são resultantes de certos estímulos, gerando a interpretação das propriedades intrínsecas aos 
produtos. Para isto, é preciso que haja contato e interação entre as partes. Os estímulos são medidos por processo físicos e químicos e as sensações por efeitos psicológicos. As sensações produzidas podem dimensionar a intensidade, extensão, permanência, qualidade, gosto ou desgosto em relação ao produto avaliado. Nesta avaliação, os indivíduos, por meio dos próprios órgãos sensoriais, numa percepção somato-sensorial, utilizam os sentidos da visão, olfato, audição, tato e gosto (BRASIL, 2005).

Os refrescos não apresentaram diferença sensorial significativa quanto aos atributos, aroma, sabor e avaliação global, mas apresentaram diferença sensorial significativa quanto à aparência (Tabela 16).

Tabela 16. Significâncias estatísticas obtidas pelo teste $F$ para as análises sensoriais realizadas nos refrescos adoçados de jabuticaba a $12^{\circ}$ Brix.

\section{Parâmetros}

Teor de sólidos solúveis do xarope

$\left(60\right.$ e $70^{\circ}$ Brix $)$
$*$

ns

ns

ns

Teste F: * significativo ao nível de $5 \%$ de probabilidade $(0,01 \leq \mathrm{p}<0,05)$; ns não significativo $(\mathrm{p} \geq 0,05)$.

O teor de sólidos solúveis presente nos xaropes (60 e $70^{\circ}$ Brix) interferiu significativamente na aparência das bebidas (Tabela 17). Os refrescos adoçados de jabuticaba provenientes da diluição do xarope $60^{\circ}$ Brix continham maior teor de fruta na sua composição fazendo com que exibissem uma cor mais intensa, fato este responsável pelas melhores notas para o atributo aparência, mas somente este atributo não foi suficiente para alterar a avaliação global. 
Tabela 17. Comparação de médias, seguidas pelo desvio padrão, dos atributos sensoriais aparência, aroma, sabor e avaliação global dos refrescos de jabuticaba a $12^{\circ}$ Brix.

Teor de sólidos solúveis dos xaropes

\begin{tabular}{ccccc} 
Parâmetros & $\mathbf{6 0}^{\circ}$ Brix & $\mathbf{7 0}^{\circ}$ Brix & Média & C. V. (\%) \\
\hline Aparência & $7,37 \pm 1,22^{\mathbf{a}}$ & $6,73 \pm 1,48^{\mathbf{b}}$ & $7,05 \pm 1,39$ & 19.26 \\
Aroma & $6,18 \pm 1,42$ & $5,93 \pm 1,40$ & $6,06 \pm 1,41$ & 23.28 \\
Sabor & $6,96 \pm 1,46$ & $6,83 \pm 1,56$ & $6,9 \pm 1,51$ & 21,93 \\
$\begin{array}{c}\text { Avaliação } \\
\text { Global }\end{array}$ & $6,95 \pm 1,23$ & $6,68 \pm 1,32$ & $6,82 \pm 1,28$ & 18,70 \\
\hline
\end{tabular}

*Médias de três repetições \pm desvio padrão. As médias seguidas pela mesma letra na linha não diferem estatisticamente entre si. Foi aplicado o Teste t ao nível de 5\% de probabilidade. 


\section{CONCLUSÃO}

Conforme os resultados obtidos nesse trabalho, visando o aproveitamento tecnológico e agregação de valor à jabuticaba recomenda-se a produção de refrescos a $12^{\circ}$ Brix a partir do método de extração utilizando o fruto inteiro com fabricação de xaropes a $60^{\circ}$ Brix. 


\section{REFERÊNCIAS}

ASSOCIAÇÃO BRASILEIRA DE NORMAS TÉCNICAS. NBR 12806: análise sensorial dos alimentos e bebidas. Rio de Janeiro, 1993. 8 p.

ANDERSEN, O.; ANDERSEN, V. U. As frutas silvestres brasileiras. 3. ed. São Paulo: Globo, 1989. 203 p.

ASCHERI, D.P.R.; ASCHERI, J.L.R.; CARVALHO, C.W.P. Caracterização da farinha do bagaço da jabuticaba e propriedades funcionais dos extrusados. Ciência de Tecnologia de Alimentos, v. 26, p. 867-905, 2006.

ATKINS, P.; JONES, L. Princípios de química. 3. ed. Porto Alegre: Bookman, 2006. 968 p.

BLIGH, E. G.; DYER; W. J. A rapid method of total lipid extraction and purification. Canadian Journal of Biochemistry and Physiology, Ottawa, v. 37, p. 911-917, 1959.

BORGES, M. H. C. B; MELO, B. Cultura da jabuticabeira. Uberlândia: Núcleo de Estudo em Fruticultura no Cerrado. Disponível em:

<http://www.fruticultura.iciag.ufu.br/jabuticaba.html>. Acesso em: 13 dez. 2013. 
BRASIL. Ministério da Saúde. Agência Nacional de Vigilância Sanitária. Tabela brasileira de composição de alimentos- TACO. 4 ed. Campinas, 2011.164 p.

BRASIL. Ministério da Saúde. Agência Nacional de Vigilância Sanitária. Resolução RDC $\mathrm{n}^{\circ} 360$, de 23 de dezembro de 2003. Regulamento Técnico sobre Rotulagem Nutricional de Alimentos Embalados. Diário Oficial da União, Brasília, DF, 26 de dezembro de 2003. Disponível em: < http://portal.anvisa.gov.br/wps/wcm/connect/1c2998004bc50d62a671ffbc0f9d5b29/RDC_ N_360_DE_23_DE_DEZEMBRO_DE_2003.pdf?MOD=AJPERES > Acesso em: 8 jan. 2014.

BRASIL. Ministério da Saúde. Agência Nacional de Vigilância Sanitária. Métodos Físicoquímicos para Análise de Alimentos. 4. ed. Brasília: Ministério da Saúde, 2005. 1018 p.

BRASIL. Decreto No 6.871, de 4 de Junho de 2009. Regulamenta a Lei no 8.918, de 14 de julho de 1994, que dispõe sobre a padronização, a classificação, o registro, a inspeção, a produção e a fiscalização de bebidas. Diário Oficial da União, Brasília, DF, 4 jun. 2009. p. 20. Disponível em: < http://www.planalto.gov.br/ccivil_03/_Ato20072010/2009/Decreto/D6871.htm>. Acesso em: 8 jan. 2014.

BRUNINI, M. A. et al. Influência de embalagens e temperatura no armazenamento de jabuticabas (Myrciaria jabuticaba (Vell) Berg) cv 'SABARÁ'. Ciência e Tecnologia de Alimentos, v.24, n.3, p. 378-383, 2004.

CAMPOS, C. R. et al. Avaliação do processo fermentativo da bebida alcoólica de jabuticaba (Myrciaria cauliflora Berg) In: congresso brasileiro de Ciências e Tecnologia de Alimentos, 13.,2002, Porto Alegre. Anais... Porto Alegre: SBCTA, 2002, p.932-935. 1 CD-ROM.

CECCHI, H. M. Fundamentos teóricos e práticos em análise de alimentos. 2. ed. Campinas: Editora da Unicamp, 2003. 207 p.

CHITARRA, M. I. F.; CHITARRA, A. B. Pós-colheita de frutos e hortaliças: fisiologia e manuseio. Lavras: UFLA, 2005. 783 p.

CITADIN, I.; DANNER, M. A.; SASSO, S. A. Z. Jabuticabeiras. Revista Brasileira de Fruticultura, Jaboticabal, v. 32, n. 2, p. 343-656, jun. 2010.

COPERSUCAR. Amostragens e análise de cana-de-açúcar. São Paulo: Centro de Tecnologia Copersucar, 2001. 80 p.

DANNER, M. A. et al. Enraizamento de jabuticabeira (pliniatrunciflora) por mergulhia aérea. Revista Brasileira de Fruticultura, Jaboticabal, v. 28, n. 3, p.530-532, dez. 2006.

DE MARCHI, R. Bebida de maracujá natural "light" pronta para beber: formulação, produção e estudo de vida-de-prateleira. 2006. $206 \mathrm{f}$. Tese (Doutorado em Alimentos e Nutrição)-Faculdade de Engenharia de Alimentos, Universidade Estadual de Campinas, Campinas, 2006. 
DONADIO, L. C. Jabuticaba (Myrciaria jaboticaba (Vell.) berg). Jaboticabal: Funep, 2000. 55 p. (Série Frutas Nativas, 3).

DONADIO, L. C.; MÔRO, F. V.; SERVIDONE, A. A. Frutas Brasileiras. Jaboticabal: Funep, 2002. 288 p.

GOMES, R. P. A jabuticabeira. In: GOMES, R. P. Fruticultura Brasileira. 12. ed. São Paulo: Nobel, 1972. p. 263-267.

JACQUES, A. C. et al. Nota científica: compostos bioativos em pequenas frutas cultivadas na região sul do Estado do Rio Grande do Sul. Brazilian Journal of Food

Technology, Campinas, v. 12, n. 2, p.123-127, abr. 2009.

LIMA, A. J. B. et al. Caracterização do fruto jabuticaba (Myrciariacauliflora Berg) e de suas frações. Archivos Latino Americanos de Nutricion, v. 58, n. 4, p. 416-421, 2008.

MAGALHÃES, M. M; BARROS, R. S; FINGER, F. L. Changes in structural carbohydrates in developing fruit of Myrciaria jaboticaba. Scientia Horticulturae, v. 66, p. 17-22, 1996.

MANICA, I. Frutas nativas, silvestres e exóticas 1: técnicas de produção e mercado: abiu, amora-preta, araçá, bacuri, biribá, carambola, cereja-do-rio-grande, jabuticaba. Porto Alegre: Cinco Continentes, 2000. 327 p.

MATTOS, J. L. R. Fruteiras nativas do Brasil: jabuticabeiras. Porto Alegre: Nobel, 1983. $92 \mathrm{p}$.

OCHSE, J. J. et al. Tropical and subtropical agriculture. 3rd. ed. New York: The Macmillan Company, 1961. v. 3, p. 684-686.

OLIVEIRA, A.L. et al. Caracterização tecnológica de jabuticabas 'Sabará' provenientes de diferentes regiões de cultivo. Revista Brasileira de Fruticultura, Jaboticabal, v. 25, p. 397-400, 2003.

OLIVEIRA, D. T. Impactos dos itens da especificação da qualidade do açúcar na indústria alimentícia In: CONGRESSO BRASILEIRO DE CIÊNCIA E TECNOLOGIA DE ALIMENTOS, 20., 2006, Curitiba. Qualidade do açúcar para a indústria alimentícia: anais... Campinas: Unicamp, 2006. 1 CD-ROM.

PEREIRA, M. C.T. et al. Atributos físicos e químicos de frutos de oito clones de jabuticabeiras. Revista Brasileiras de Fruticultura, Jaboticabal, v 22, p 16 - 21, 2000.

QUEIROZ, E. C. Utilização dos isótopos estáveis de carbono e nitrogênio na detecção de adulteração e avaliação energética de bebidas de laranja. $2005.73 \mathrm{f}$. Tese (Doutorado em Agronomia/Energia na Agricultura)-Faculdade de Ciências Agronômicas, Universidade Estadual Paulista, Botucatu, 2005.

SASSO, S. A. Z. et al. Propagação de jabuticaba por estaquia. Revista Brasileira de Fruticultura, Jaboticabal, v. 32, n. 2, p. 577-583, jun. 2010. 
SATO, A. C. K; CUNHA, R. L. Influência da temperatura no comportamento reológico da polpa de jabuticaba. Ciência e Tecnologia de Alimentos, Campinas, v. 27, n. 4, p. 890896, 2007.

SIMÕES, C.M.O. et al. Farmacognosia, da planta ao medicamento. Porto Alegre: Editora da Universidade UFRGS/UFSC, 2000. 821 p.

TEMPORADA das jabuticabas. Goiânia: Aldeia Acabamento e Complementos, 2012. Disponível em: <http://aldeiatem.com/blog/?p=8570>. Acesso em: 20 jan. 2014.

TERCI, D. B. L. Aplicações analíticas e didáticas de antocianinas extraídas de frutas. 2004. 213 p. Tese (Doutorado em Química Analítica)-Instituto de Química, Universidade de Campinas, Campinas, 2004.

UNIVERSIDADE FEDERAL DO RIO GRANDE DO SUL. Unidades de Calor. 2002. Organizado por Maria Beatriz dos Santos Almeida Moraes. Disponível em:

<http://www.if.ufrgs.br/mpef/mef008/mef008_02/Beatriz/unidades.htm>. Acesso em: 8 jan. 2014.

ZICKER, M. C. Obtenção e utilização do extrato aquoso de jabuticaba (myrciaria jabuticaba (vell) berg) em leite fermentado: caracterização físico-química e sensorial. 2011. 137 f. Dissertação (Mestrado em Ciência de Alimentos)-Faculdade de Farmácia, Universidade Federal de Minas Gerais, Belo Horizonte, 2011. 


\section{APÊNDICE}

\section{APÊNDICE 1}

Termo de consentimento livre e esclarecido que foi entregue a todos os participantes das análises sensoriais.

\section{TERMO DE CONSENTIMENTO LIVRE E ESCLARECIDO}

O sr(a) está sendo convidado(a) a participar de uma pesquisa chamada "Caracterização físico-química e sensorial de refresco adoçado de jabuticaba e aproveitamento do bagaço para a produção de etanol", que pretende produzir e analisar físico-química e sensorialmente refresco adoçado de jabuticaba, sendo sua função avaliar qual o melhor método de produção do mesmo. O refresco adoçado de jabuticaba apresenta em sua composição suco natural da fruta, água filtrada e açúcar cristal, caso você possua alergia a algum destes compostos você não poderá participar da pesquisa.

Devido ao elevado teor de água e açúcares presentes na polpa a jabuticaba é uma fruta altamente perecível. Embora a jabuticaba seja uma fruta com características nutricionais e sensoriais interessantes, os frutos não tem tido aproveitamento comercial, devido à elevada perecibilidade e curto período de safra. Diante disso, há necessidade de estudos relacionados ao processamento desta fruta, permitindo que, através do conhecimento dessas características, produtores rurais adquiram alternativas de renda a partir dessas técnicas de produção.

Nos testes sensoriais, serão servidos $50 \mathrm{~mL}$ de cada amostra, com o máximo de três amostras por sessão. Será realizada apenas uma sessão de análise por dia, os provadores não precisam ingerir toda a quantidade servida, apenas a quantidade que julgar suficiente para formular as respostas dos testes.

O provador participará de um dia de análise e poderá retirar seu consentimento, em qualquer fase da pesquisa sem nenhum prejuízo. É garantido total sigilo do seu nome em relação aos dados relatados nesta pesquisa. Você receberá uma via deste termo, e outra via será mantida em arquivo pelo pesquisador por cinco anos. Qualquer dúvida adicional, você poderá entrar em contato com o Comitê de Ética em Pesquisa, através do fone: (14) 3880-1608 / 1609. 


\section{CONCORDO EM PARTICIPAR DA PESQUISA}

Nome:

Assinatura:

Data:________ Assinatura

Pesquisador:

Pesquisadora responsável: Francine Fricher Boesso

Rua Alfredo Leitão , 37 - Centro - Jaú/SP Fone: (014) 97776083 E-mail:

franboesso@fca.unesp.br

Orientador: Waldemar Gastoni Venturini Filho

Rua Augusto Martins, 135 - Parque Residencial Primavera - Botucatu/SP Fone: (014) 38155470

E-mail: Venturini@fca.unesp.br

Faculdade de Ciências Agronômicas - Departamento de Horticultura 


\section{APÊNDICE 2}

Autorização do comitê de ética em pesquisa para a realização das análises sensoriais.

Título da Pesquisa: CARACTERIZAÇÃO FÍSICO-QUÍMICA E SENSORIAL DE REFRESCO ADOÇADO DE JABUTICABA E APROVEITAMENTO DO BAGAÇO PARA A PRODUÇÃO DE ETANOL

Pesquisador: Francine Fricher Boesso

Versão: 2

CAAE: 20846213.7.0000.5411

Instituição Proponente: Departamento de Horticultura

Situação: Aprovado

Localização atual do Projeto: Pesquisador Responsável 